\title{
The Peñafiel Vocabulary from San Juan Elotepec
}

\author{
Natalie Operstein \\ University of California
}

This paper analyzes and makes available the contents of an unpublished nineteenth-century lexical questionnaire in Elotepec Zapotec, an endangered and under-documented indigenous language of Mexico. This unique document forms part of the survey of Mexican indigenous languages conducted in the 1880s and 1890s by the Dirección General de Estadística de la República Mexicana. The paper provides a transcription of the Elotepec Zapotec forms, a study of the document's orthography, and a linguistic analysis of the data.

\section{Introduction}

In the 1880s, Antonio Peñafiel Barranco, head of the newly founded Dirección General de Estadística de la República Mexicana, launched a far-flung, multiyear survey of the indigenous languages of Mexico. ${ }^{1}$ The goal of the survey was to assemble basic, practical information about the languages in order to catalog them, determine their geographical distribution, assess their vitality and, in some cases, "consignar idiomas que no eran conocidos, como el cahuilla de la Baja California" [to record languages that were not known, like Cahuilla from Baja California] (Peñafiel 1897: 93). The practical orientation of the survey was emphasized in Peñafiel's report to the Eleventh Congress of Americanists, held in Mexico City in 1895:

No se quería la clasificación de las lenguas, ni concienzudos estudios de Filología, sino simplemente una recopilación, un catálogo general comparativo para aplicaciones útiles y prácticas .... (Peñafiel 1897: 92) ${ }^{2}$

The survey instrument consisted of a numbered list of 250 lexical items in Spanish which were to be translated into the various indigenous languages by local residents (Peñafiel 1897: 93). The thematic breakdown of the word list is as shown in (1).

\footnotetext{
${ }^{1}$ The precise beginning and end dates of the survey are somewhat unclear. Bright (1967) and Suárez (1972) each note that the dates of the Peñafiel vocabularies examined by them ranged between 1880 and 1894. On the other hand, Peñafiel observes in his presentation to the Eleventh Congress of Americanists that assembling the vocabularies has taken him nine years (Peñafiel 1897: 92). The Dirección General de Estadística was founded in 1882; Peñafiel served as its general director for 28 years, beginning in 1883 (INEGI 2009: 20).

2 "What was wanted was neither classification of the languages nor painstaking philological study but rather a simple compilation, a general comparative catalog for functional and practical uses".
} 


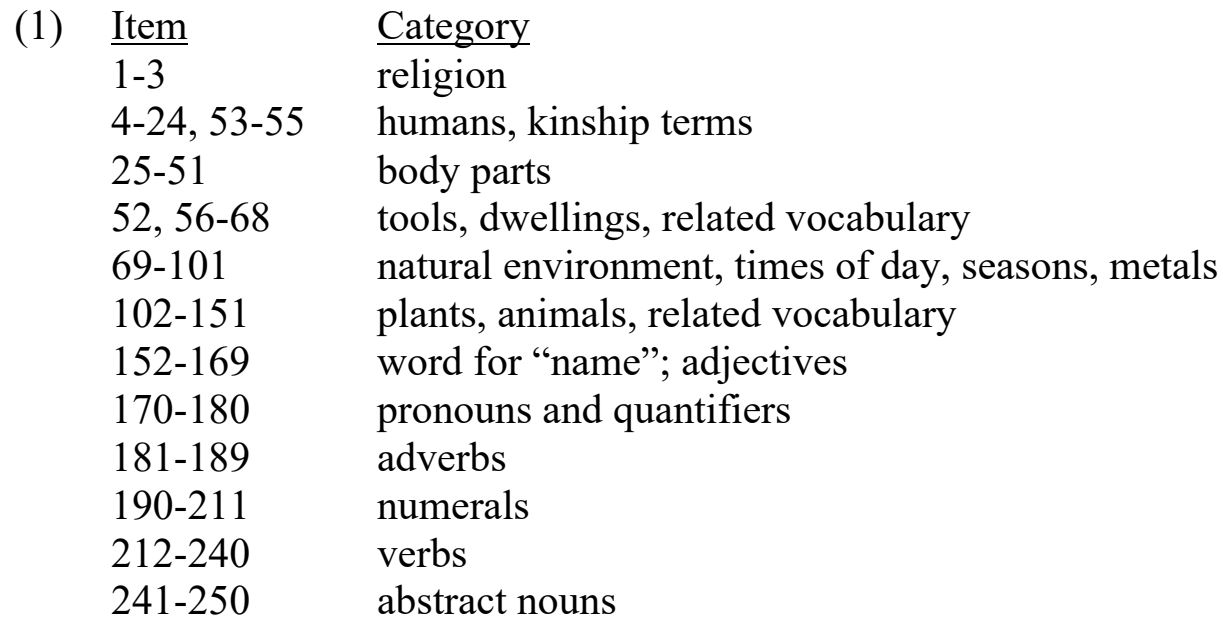

Since the Peñafiel questionnaires were filled out by individuals who "had no previous experience in work of this kind", they necessarily vary in quality and accuracy (Mechling 1912: 643). Though some have previously been used for linguistic research (Mechling 1912; Smith Stark 1999), only a fraction have been published, and the observations below appear to be as accurate today as at the time of their publication more than a century ago:

In the year 1886 Dr Antonio Peñafiel collected vocabularies of native languages from all parts of Mexico .... The volume of these vocabularies that has been printed deals entirely with the well-known Mexican of the Central Plateau region .... With the other four volumes into which Peñafiel divides his manuscripts nothing has been done, although it is hoped that they will soon be published by the Mexican Government. (Mechling 1912: 643)

Among the Peñafiel vocabularies that have not yet been published or analyzed is the one from the town of San Juan Elotepec. The language it records, Elotepec Zapotec (ISO code zte), is only scantily documented, the only publications on this variety being an eighteen-page long Breve noticia del idioma papabuco del pueblo de Elotepec by Francisco Belmar (Belmar 1901) and an about twenty-page long article by Juan José Rendón (Rendón 1971). The latter researcher was unable to reach the town of San Juan Elotepec due to heavy rains and had to settle for conducting his fieldwork in the vicinity.

Elotepec Zapotec is one of the three languages that form the Papabuco branch of Zapotec, the other two being Zaniza Zapotec (ISO code $z p w$; see Operstein 2015a, 2015b, 2016, 2017b) and Texmelucan Zapotec (ISO code $z p z$; see Speck 1978, 2005a, 2005b). ${ }^{3}$ The Ethnologue (Eberhard et al. 2019) reports Elotepec Zapotec's intelligibility with Zaniza Zapotec as 68\% and with Texmelucan Zapotec as 10\%; its most recently reported vitality level is 8 a ("moribund"). In light of its critical endangerment and a severe dearth of both primary data and published research, it is hoped that the present paper will provide a stimulus for undertaking systematic documentation of Elotepec Zapotec, as well as a basis for its inclusion in historical and comparative research on Zapotec and Zapotecan languages. Since the Peñafiel vocabulary reflects the state of Elotepec Zapotec in the late 1880s, it also provides a unique dataset with which to observe linguistic change in a Zapotec language over the period of more than a century.

\footnotetext{
${ }^{3}$ These publications are the source of the Texmelucan Zapotec forms cited in the paper.
} 
The paper is organized as follows. Section 2 provides a general description of the Peñafiel vocabulary from San Juan Elotepec. Sections 3 and 4 focus on the consonant and vowel inventories of Elotepec Zapotec, respectively, paying particular attention to the orthographic representation of the phonological contrasts. Section 5 looks at the morphological and syntactic features of Elotepec Zapotec reflected in the responses, and section 6 examines the Spanish loanwords in the data. Section 7 discusses the apparent misunderstandings and occasional errors, as well as the responses in Elotepec Zapotec that, for now, remain unanalyzed. Section 8 closes the paper with concluding remarks.

\section{Peñafiel vocabulary from San Juan Elotepec}

The vocabulary from San Juan Elotepec appears on the folios 656 through 659 of the manuscript identified by Jorge Suárez (1972: 231) as Lenguas indígenas de Oaxaca (see Peñafiel 18801894). The vocabulary consists of eight photocopied pages and comprises printed and handwritten text. The centered printed heading at the top of the title page states in large block letters "Dirección General de Estadística de la República Mexicana" and is followed by the centered heading, in smaller block letters, stating "Instrucciones sobre la etnología y filología nacionales". Underneath is the following list of preliminary questions, printed in italics, and the corresponding handwritten answers:

\begin{tabular}{|c|c|}
\hline Nombre del Estado & Oaxaca $=$ Lolá \\
\hline Id. del Municipio & Agencia \\
\hline Id. del Pueblo & San Juan Elotepec, Tieyé es Zuá \\
\hline Id. del idioma & Zapotece Papabuco \\
\hline Id. del gentílico en que se habla & Entre Zapoteco y Chatino \\
\hline $\begin{array}{l}\text { Nombre de la persona que escriba las palabras que } \\
\text { corresponden á las castellanas escritas por órden } \\
\text { numérico }\end{array}$ & $\begin{array}{l}\text { C. Lorenzo Salinas, soltero de } 22 \\
\text { años, actual secretario del municipio }\end{array}$ \\
\hline $\begin{array}{l}\text { Fecha y lugar en que se escribe la traduccion de este } \\
\text { vocabulario }\end{array}$ & \\
\hline
\end{tabular}

Immediately underneath is the centered heading "Vocabulario comparativo", printed in block letters and followed by a numbered list of 250 lexical entries.

The handwritten part of the vocabulary evidences what appear to be three different hands. The anwers to the preliminary questions above and the responses to the quesionnaire all appear to be written by the same hand, presumably that of Lorenzo Salinas. The other two handwritings are confined to the title page. One is seen in the words "Oaxaca" and "Villa alvarez", written close to the top of the page, and the other is responsible for the words "C. Presidente mpal de S. Juan Elotepec" on the very top of the page, and for the word "Papabuco", which is written twice, first next to and after crossing out Salinas's response "Zapoteco" to the question Id. del idioma [name of the language], and then again above the printed heading "Vocabulario comparativo" (see Figure 1). ${ }^{4}$

\footnotetext{
${ }^{4}$ The fact that the person who filled out the questionnaire identified the language as Zapotec rather than Papabuco is commented upon by Suárez (1972: 229), who also reminds us of Belmar's observation that "in the administrative memory of 1873" the language of San Juan Elotepec was called Zapotec rather than Papabuco (see Belmar 1901: 4).
} 
In its top left-hand margin the title page bears an oval seal with the Mexican coat of arms and the words "Municipalidad S. Juan Elotepec" printed around its edge. The same seal appears in the bottom left-hand margin of the last page, to the left of what appears to be Salinas's signature under two handwritten lines, which are not legible on my copy. Jorge Suárez, whose research was conducted with the help of the original Peñafiel manuscript, gives the date of the Elotepec Zapotec vocabulary as 1886 (Suárez 1972: 220, fn. 2; 229).

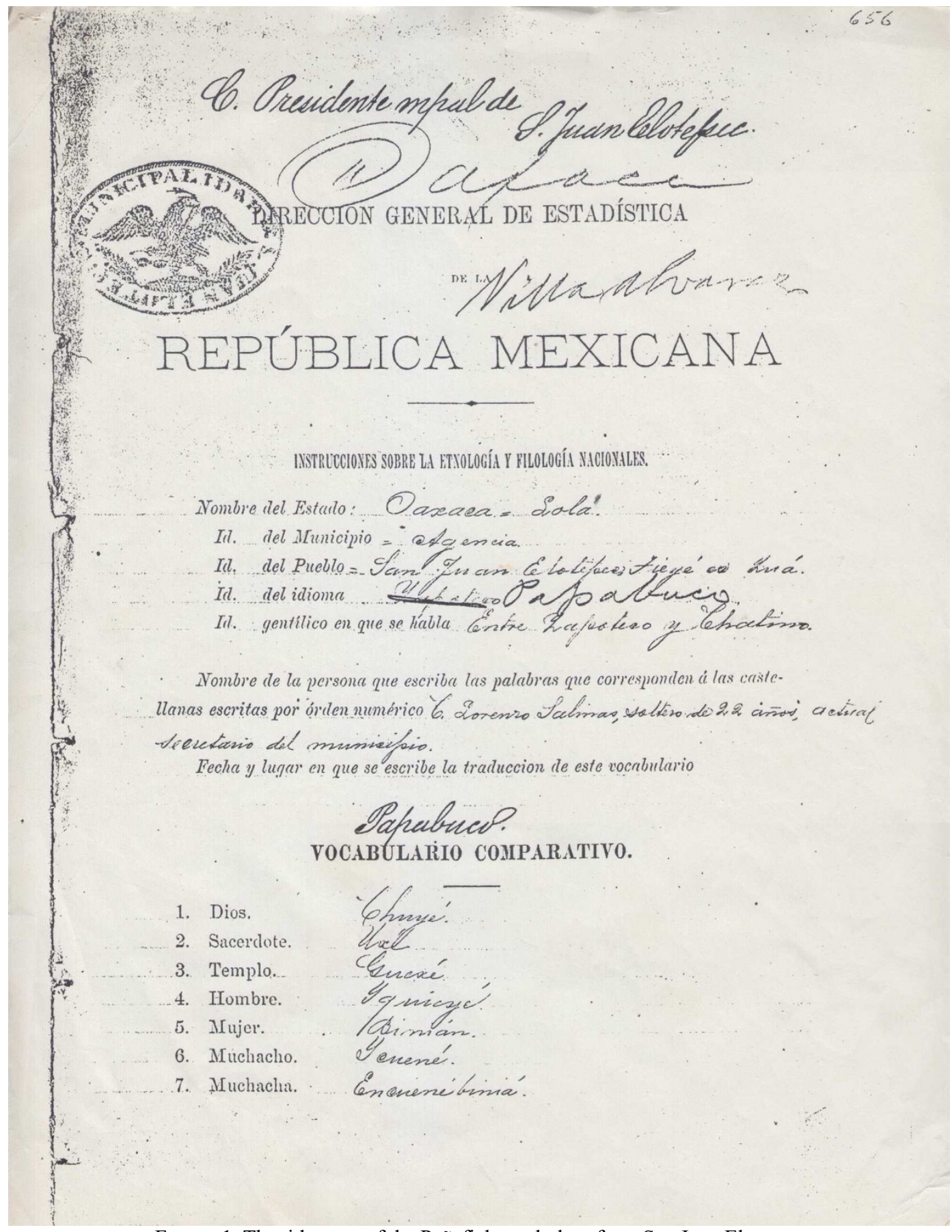

FiguRE 1. The title page of the Peñafiel vocabulary from San Juan Elotepec 


\section{Elotepec Zapotec consonants}

The consonant inventory of Elotepec Zapotec which may be deduced from the orthography of the Peñafiel vocabulary, supplemented by Belmar's (1901) and Rendón's (1971) orthographies and observations and a comparison with the other Papabuco languages, is shown in Table 1. The fricatives $/ \mathrm{f} /$ and $/ \mathrm{h} /$ are confined to Spanish borrowings; apparent distributional gaps in native words include the absence of morpheme-initial $/ \mathrm{p} /$ and $/ 3 /$ and root-medial $/ K /, / \mathrm{k}^{\mathrm{w}} /$ and $/ \mathrm{g}^{\mathrm{w}} /$.

\begin{tabular}{|c|c|c|c|c|c|c|c|}
\hline $\mathrm{p}$ & $\mathrm{t}$ & & & & $\mathrm{k}$ & $\mathrm{k}^{\mathrm{w}}$ & \\
\hline $\mathrm{b}$ & $\mathrm{d}$ & & & $\mathrm{g}^{\mathrm{1}}$ & $\mathrm{g}$ & $\mathrm{g}^{\mathrm{w}}$ & \\
\hline & $\mathrm{r}$ & & & & & & \\
\hline & & & $\mathrm{t} \int$ & & & & \\
\hline & & & $\mathrm{d} 3$ & & & & \\
\hline (f) & $\mathrm{s}$ & $\mathrm{s}$ & $\mathrm{J}$ & & & & (h) \\
\hline & $\mathrm{z}$ & $\mathrm{z}$ & 3 & & & & \\
\hline $\mathrm{m}$ & $\mathrm{n}$ & & $\mathrm{n}$ & & & & \\
\hline & $\mathrm{l}$ & & $\kappa$ & & & & \\
\hline $\mathrm{w}$ & & & $\mathrm{j}$ & & & & \\
\hline
\end{tabular}

Table 1. Elotepec Zapotec consonants

The status of the consonant provisionally represented in Table $1 \mathrm{as} / \mathrm{g}^{\prime} /$ is unclear; this is one possible interpretation of the recurrent orthographic sequence $<$ gui $>\sim<$ qui $>$ before $<$ a $>$ and $<$ e $>$ (see Table 2).

\begin{tabular}{|c|c|c|c|c|}
\hline ELOTEPEC & ZANIZA & TEXMELUCAN & PROTO-ZAPOTEC 5 & \\
\hline$<$ guiagua $>$ & /dzaaw/ & /Joow/ & *ke:?ku & 'river' \\
\hline$<$ quial(dó) $>$ & /dzal (doo)/ & /ృel/ & *ke?la & 'lake' \\
\hline$<$ quia(ná) $>$ & /gi'/ & $/ \mathrm{Ji}{ }^{\prime} /$ & *k-i?ja & 'foot' \\
\hline$<$ guieté $>$ & /get/ & /Jet/ & *kettu & 'squash' \\
\hline$<$ quieiyé $>$ & /gej/ & /цеј/ & *kijok & 'rain' \\
\hline$<($ y)quieyé $>$ & /(i)gej/ & /(ju) Jeej/ & $*\left(\mathrm{k}^{\mathrm{w}} \mathrm{e}-\right) \mathrm{ki}$ iju & 'man' \\
\hline$<($ ez)quin(cazá) $>$ & /(si)gin/ & $/\left(\mathrm{t} \int \mathrm{i}\right) \mathrm{Jin} /$ & $*\left(\mathrm{k}^{\mathrm{w}} \mathrm{e}-\right)$ kinni & 'bird' \\
\hline < guiñí $>$ & /gin/ & /Jiij/ & *ki:?na? & 'chili' \\
\hline$<$ quis(iquí)> & /gis/ & /jitg/ & $*_{k i t t z a(?)}$ & 'hair' \\
\hline$<$ quid(labá) $>$ & /gid (lab)/ & /yid (lab)/ & *kiti & 'leather' \\
\hline$<$ quib(iagá) $>$ & /gib (jag)/ & /Jib(ag)/ & ${ }^{*} \mathrm{ki}: \mathrm{Pk}^{\mathrm{w}} \mathrm{a}$ & 'metal, iron' \\
\hline
\end{tabular}

Table 2. Elotepec Zapotec /g'/

Interpreting the orthographic sequence $<$ gui $>\sim<$ qui $>$ before $<\mathrm{a}>$ and $<\mathrm{e}>$ as a single segment is suggested by the cognates in the other Papabuco languages, Rendón's (1971) use of the digraphs $<$ gy $>$ (in $<$ gya $7 \mathrm{a}^{1} \mathrm{~N}>$ 'foot') and $<\mathrm{ky}>$ (in $<\mathrm{kye}^{1} \mathrm{ye}>$ 'rain') $(226,228$ ), and Belmar's (1901) use of $<$ gui $>$ before $<$ a $>$ and $<$ e $>$ in such forms as $<$ (gal)guiaa $>$ 'height', $<$ (ru)guiao $>$ 'river mouth',

\footnotetext{
${ }^{5}$ Proto-Zapotec reconstructions are cited after Kaufman (2016). The symbols $<7>,<\mathrm{y}>,<\mathrm{kw}>$ and $<\mathrm{ty}>$ have been replaced with $\langle\mathrm{p}\rangle,\langle\mathrm{j}\rangle,\left\langle\mathrm{k}^{\mathrm{w}}\right\rangle$ and $\left\langle\mathrm{t}^{\prime}\right\rangle$, respectively.
} 
<guier(guiñi)> 'candle', <(ita)guieye> 'hail', <guieche> 'hole', <guiee> 'deep', <guieshe> 'town' and of $<$ ki $>$ in $<$ kieshe $>$ 'thorn' and $<$ kiete $>$ 'squash'. Since the Peñafiel vocabulary does not mark palatalization before $<\mathrm{i}>$ (see the words for 'bird', 'chili', 'hair', 'leather' and 'metal, iron' in Table 2), the orthographic $<\mathrm{gu}>\sim<\mathrm{qu}>$ in that environment is interpreted as $/ \mathrm{g} /$.

Table 3 illustrates the occurrence of Elotepec Zapotec consonants other than $/ \mathrm{g}^{\prime} /$ in initial and medial positions. The Elotepec forms are transcribed in IPA and, where applicable, are divided into morphemes. The morphemes in the Elotepec responses which are not anticipated by the corresponding Spanish prompts, such as the first person plural pronoun clitic - $n a$, are enclosed in brackets.

\begin{tabular}{|c|c|c|c|c|c|}
\hline \multirow[t]{2}{*}{$/ \mathrm{p} /$} & $/$ tapa $/<$ tapa $>$ & 'four' & \multirow[t]{2}{*}{$/ \mathrm{s} /$} & /şona/ <zosná> & 'three' \\
\hline & / 1 opa/ <llopa $>$ & 'six' & & /gisi ru(-na)/ < quisi runá> & 'beard' \\
\hline \multirow[t]{2}{*}{$/ \mathrm{b} /$} & $/$ bi $/<$ viy $>$ & 'wind' & \multirow[t]{2}{*}{$|z|$} & /zini/ <lliní $>$ & 'deer' \\
\hline & /oba/<obá> & 'corn' & & /weze/ < guexé> & 'church' \\
\hline \multirow[t]{2}{*}{$/ \mathrm{t} /$} & $/$ tibi/ $<$ tibi $>$ & 'one' & \multirow[t]{2}{*}{$/ \mathrm{d} /$} & $/$ Sopa/ $<$ llopa $>$ & 'six' \\
\hline & /riti/ < riti $>$ & 'bone' & & /kus gife/ <cusquillé> & 'wild boar' \\
\hline \multirow[t]{2}{*}{$/ \mathrm{d} /$} & $/$ do/ < dó $>$ & 'sea' & \multirow[t]{2}{*}{$/ 3 /$} & /dzuze/ <chuyé> & 'God' \\
\hline & /bada/ < badá $>$ & 'duck' & & -- & -- \\
\hline \multirow[t]{2}{*}{$/ \mathrm{k} /$} & $/$ kola $/<$ cola $>$ & 'turkey' & \multirow[t]{2}{*}{$/ \mathrm{h} /$} & /hefe-sõ/ <jefeson $>$ & 'boss' \\
\hline & /beko/ <beco $>$ & 'dog' & & -- & -- \\
\hline \multirow[t]{2}{*}{$/ \mathrm{g} /$} & $/$ ga/ <gá $>$ & 'nine' & \multirow[t]{2}{*}{$/ \mathrm{m} /$} & $/ \mathrm{mil} /<\mathrm{mil}>$ & 'thousand' \\
\hline & /jaga/ <lliagá $>$ & 'wood' & & /en-mi'/ <enmihí> & 'small' \\
\hline \multirow[t]{2}{*}{$/ \mathrm{k}^{\mathrm{w}} /$} & $/ \mathrm{k}^{\mathrm{w}} \mathrm{ir}(-\mathrm{a}) /<$ cuirán $>$ & 'leg' & \multirow[t]{2}{*}{$/ \mathrm{n} /$} & /nisi/ <nisi $>$ & 'water' \\
\hline & /i-kwene/ <ycuené> & 'boy' & & $/$ kano(-re)/ <canoré $>$ & 'trough' \\
\hline \multirow[t]{2}{*}{$/ \mathrm{g}^{\mathrm{w}} /$} & $/ \mathrm{g}^{\mathrm{w}} \mathrm{i}$ il $(-$ re $) /<$ cuiilré $>$ & 'star' & \multirow[t]{2}{*}{$/ \mathrm{n} /$} & /ner jeja/ $<$ nierrieñá $>$ & 'neck' \\
\hline & $/$ i-gwi(-na)/ < higuiná $>$ & 'see' & & /bana/ <baña $>$ & 'horse' \\
\hline \multirow[t]{2}{*}{$/ \mathrm{t} \mathrm{f} /$} & $/ \mathrm{t} \int \mathrm{o} /<\mathrm{chó}>$ & 'forty' & \multirow[t]{2}{*}{$/ \mathrm{r} /$} & /riti/ < riti $>$ & 'bone' \\
\hline & $/(\mathrm{m})$ bet $\int \mathrm{e} /<$ beché $>$ & 'people' & & /uraga/ <uraga $>$ & 'dove' \\
\hline \multirow[t]{2}{*}{$/ \mathrm{d} 3 /$} & /dzuze/ <chuyé> & 'God' & \multirow[t]{2}{*}{$/ 1 /$} & $/$ lede/ $<$ ledé $>$ & 'bark' \\
\hline & /gedze/ < gueché> & 'seven' & & $/$ bala/ <balá $>$ & 'meat' \\
\hline \multirow[t]{2}{*}{$/ \mathrm{f} /$} & /fletfe-sõ/ <fleche essón $>$ & 'arrow' & \multirow[t]{2}{*}{$/ K /$} & / Kaga/ <leagá $>$ & 'leaf' \\
\hline & /hefe-sõ / <jefeson $>$ & 'boss' & & $/$ / ag(-ге) / <liagré $>$ & 'grass' \\
\hline \multirow[t]{2}{*}{$/ \mathrm{s} /$} & /solteré/ <solteré $>$ & 'young' & \multirow[t]{2}{*}{$/ \mathrm{w} /$} & /wezel/ < guexé> & 'church' \\
\hline & /nisi/ <nisi $>$ & 'water' & & /g'awa/ < guiagua $>$ & 'river' \\
\hline \multirow[t]{2}{*}{$/ \mathrm{z} /$} & /zede/ <zedé> & 'salt' & \multirow[t]{2}{*}{$/ \mathrm{j} /$} & /ju'/ <yuhú $>$ & 'house' \\
\hline & /uze/ <uxé> & 'priest' & & /beje/ <beyé> & 'moon' \\
\hline
\end{tabular}

Table 3. Examples of Elotepec Zapotec consonants

The orthographic representation of Elotepec consonants in the Peñafiel vocabulary relies on Spanish orthographic conventions. These include representation of velar stops by means of $<$ qu $>$, $<\mathrm{gu}>$ or $\langle\mathrm{c}>,<\mathrm{g}>$ depending on whether the following vowel is front or back, the use of both $<\mathrm{b}>$ and $\langle\mathrm{v}>$ to spell $/ \mathrm{b} /$, and an occasional silent $<\mathrm{h}>$. Innovative uses of Spanish orthographic devices are found in the representation of Elotepec sounds that do not occur in Spanish; some of these, like the use of $\langle y>$ to represent palatal fricatives, may have been inspired by pronunciations current in local Spanish (see, e.g., Alvar 1965-1966: 360-362 and Lope Blanch 1966:52 on rehilamiento, or fricative realization of $/ y /$, spelled $<\mathrm{y}>,<1 \mathrm{l}>$, in Oaxacan Spanish). 
Interpretation of the surface phonetics of some of the spellings is helped by comparison with Zaniza and/or Texmelucan Zapotec cognates.

The greatest challenge for the transcriber was posed by the coronal fricatives of Elotepec Zapotec (see Table 4). In some cases, the same grapheme or digraph is used for spelling different fricatives; for example, $<\mathrm{x}>$ stands for /z/ in <uxé $>$ 'priest', /z/ in $<$ guexé $>$ 'church' and / $/$ in $<$ xilquité $>$ '(rain)bow'. In other cases, the same fricative receives multiple orthographic representations; for instance, $/ \mathrm{z} /$ is represented by $<\mathrm{x}>$ in $<$ uxé $>$ 'priest', by $<\mathrm{s}>$ in $<$ usanré $>$ 'my father' and by $<\mathrm{z}>$ in $<$ zedé $>$ 'salt'. The different orthographic solutions may be found in the spelling of the same morpheme: compare <bizná> (/(m)biz-na/) 'fingers' with <bisilná> (/(m)biz-il-na/) 'thumb' or the spelling of the animacy prefix in <esquinloyec $>$ 'bird' and <esquienú> 'mosquito', on the one hand, and <ezquincazá> 'crow' and <ezquiegué> 'fly', on the other. The native fricatives are thus orthographically under-distinguished, both with respect to their place of articulation and voicing (or, more accurately, their distinction along the fortis/lenis dimension, partially realized through voicing) (Nellis \& Hollenbach 1980; Avelino 2001; Pickett et al. 2010; Operstein 2016). The velar and labiovelar stops, and the affricates are also underdistinguished with respect to the fortis/lenis distinction; for example, $<\mathrm{ch}>$ is used for $/ \mathrm{t} f /$ in $<$ cho $>$ 'forty' and <beché> 'people', on the one hand, and for $/ \mathrm{d}_{3} /$ in $<$ chuyé $>$ 'God' and $<$ gueché> 'seven', on the other (cf. /t fu/, /mbet $\int \mathrm{e} /$, /dzuz/ and /gadz/ in Zaniza Zapotec).

\begin{tabular}{|c|c|c|c|c|}
\hline \multirow[t]{2}{*}{$/ \mathrm{p} /$} & $<\mathrm{p}>$ & & & \\
\hline & $<$ tapa $>$ 'four' & & & \\
\hline \multirow[t]{2}{*}{$/ \mathrm{b} /$} & $<\mathrm{b}>$ & $<\mathrm{v}>$ & & \\
\hline & $<$ beyé> 'moon' & $<$ viy $>$ 'wind' & & \\
\hline \multirow[t]{2}{*}{$/ \mathrm{t} /$} & $<\mathrm{t}>$ & & & \\
\hline & $<$ tiñia $>$ 'nose' & & & \\
\hline \multirow[t]{2}{*}{$/ \mathrm{d} /$} & $<\mathrm{d}>$ & & & \\
\hline & $<$ do $>$ 'sea' & & & \\
\hline \multirow[t]{2}{*}{$/ \mathrm{k} /$} & $<\mathrm{c}>$ & $<\mathrm{qu}>$ & & \\
\hline & $<$ cola $>$ 'turkey' & <quisiquí'> 'hair' & & \\
\hline \multirow[t]{2}{*}{$/ \mathrm{g} /$} & $<\mathrm{g}>$ & $<q u>$ & & \\
\hline & $<$ gá> 'nine' & <quisiquí> 'hair' & & \\
\hline \multirow[t]{2}{*}{$/ g^{\prime} /$} & $<\mathrm{gi}>$ & $<$ qui $>$ & $<$ gui $>$ & \\
\hline & $<$ tiomgieyé $>$ 'spring' & <quieiyé> 'rain' & $<$ guiagua $>$ 'river' & \\
\hline \multirow[t]{2}{*}{$/ \mathrm{k}^{\mathrm{w}} /$} & $<\mathrm{cu}>$ & $<q u>$ & & \\
\hline & <cuirán> 'leg' & $<$ xilquité> 'bow' & & \\
\hline \multirow[t]{2}{*}{$/ \mathrm{g}^{\mathrm{W}} /$} & $<\mathrm{cu}>$ & & & \\
\hline & <cuiillé> 'star' & & & \\
\hline \multirow[t]{2}{*}{$/ \mathrm{d} /$} & $<\mathrm{r}>$ & $<\mathrm{rr}>$ & & \\
\hline & $<$ riti > 'bone' & $<$ nierrieñá> 'neck' & & \\
\hline \multirow[t]{2}{*}{$/ \mathrm{t} f /$} & $<\operatorname{ch}>$ & & & \\
\hline & <chó> 'forty' & & & \\
\hline \multirow[t]{2}{*}{$/ d_{3} /$} & $<\operatorname{ch}>$ & & & \\
\hline & <chuyé> 'God' & & & \\
\hline \multirow[t]{2}{*}{$/ \mathrm{s} /$} & $<\mathrm{s}>$ & $<\mathrm{ss}>(?)$ & $<\mathrm{c}>$ & \\
\hline & <encasa> 'black' & $<$ fleche essón $>$ 'arrow' & $<$ bilñici > 'water snake' & \\
\hline \multirow[t]{2}{*}{ /z/ } & $<\mathrm{x}>$ & $<\mathrm{s}>$ & $<\mathrm{z}>$ & \\
\hline & <uxé> 'priest' & $<$ brisi $>$ 'squirrel' & $<$ zede $>$ 'salt' & \\
\hline \multirow[t]{2}{*}{$/ \mathrm{J} /$} & $<\mathrm{x}>$ & $<1 \mathrm{l}>$ & $<y>$ & \\
\hline & $<$ xilquité> 'bow' & $<$ llopa $>$ 'six' & $<$ heryímmá > 'to bark' & \\
\hline$/ 3 /$ & $<y>$ & & & \\
\hline
\end{tabular}




\begin{tabular}{|c|c|c|c|c|}
\hline & $<$ chuyé> 'God' & & & \\
\hline \multirow[t]{2}{*}{$/ \mathrm{s} /$} & $<\mathrm{S}>$ & $<\mathrm{Z}>$ & $<11>$ & \\
\hline & $\begin{array}{l}<\text { cusquillé }>\text { 'wild } \\
\text { boar' }\end{array}$ & <zosná> 'three' & $<$ billi $>$ 'rabbit' & \\
\hline \multirow[t]{4}{*}{$|z|$} & $<\mathrm{s}>$ & $<\mathrm{Z}>$ & $<11>$ & $<y>$ \\
\hline & $<$ billisí $>$ 'pine' & $<$ rezná $>$ 'to shout' & $<$ lliná > 'day' & $<$ tiguyé> 'town' \\
\hline & $<\mathrm{x}>$ & $<\mathrm{xh}>$ & $<\mathrm{ch}>$ & \\
\hline & <guexé> 'church' & $<$ chixhé $>$ 'coati' & $<$ chixhé $>$ 'coati' & \\
\hline \multirow[t]{2}{*}{$/ \mathrm{f} /$} & $<\mathrm{f}>$ & & & \\
\hline & $<$ jefeson $>$ 'boss' & & & \\
\hline \multirow[t]{2}{*}{$/ \mathrm{h} /$} & $<\mathrm{j}>$ & & & \\
\hline & $<$ jefeson $>$ 'boss' & & & \\
\hline \multirow{2}{*}{$/ \mathrm{m} /$} & $<\mathrm{m}>$ & & & \\
\hline & $<$ mil $>$ 'thousand' & & & \\
\hline \multirow[t]{2}{*}{$/ \mathrm{n} /$} & $<\mathrm{n}>$ & & & \\
\hline & $<$ nisi $>$ 'water' & & & \\
\hline \multirow[t]{4}{*}{$/ \mathrm{j} /$} & $<\tilde{\mathrm{n}}>$ & $<\tilde{\mathrm{n}} \mathrm{i}>$ & $<$ ni $>$ & $<\mathrm{nn}>$ \\
\hline & $<$ baña $>$ 'horse' & <reñie> 'blood' & <binián> 'woman' & $<$ beigidebesinnís $>$ 'bat' \\
\hline & $<\mathrm{n} \tilde{n}>$ & $<$ ny $>$ & & \\
\hline & <bixinñí $>$ 'mouse' & $<$ tenyia > 'bad' & & \\
\hline \multirow[t]{2}{*}{$/ 1 /$} & $<\mathrm{l}>$ & $<11>$ & & \\
\hline & $<$ ledé $>$ 'bark' & $<$ heita illi $>$ 'stone, rock' & & \\
\hline \multirow[t]{2}{*}{$/ K /$} & $<\mathrm{li}>$ & $<\mathrm{le}>$ & & \\
\hline & $<$ liagré> 'grass' & $<$ leagá > 'leaf' & & \\
\hline \multirow[t]{2}{*}{$/ \mathrm{j} /$} & $<\mathrm{y}>$ & $<$ hi $>$ & $<\mathrm{i}>$ & $<11 \mathrm{i}>$ \\
\hline & $<y u>$ 'earth' & $<$ hianá $>$ 'hand' & $<$ nierrieñá > 'neck' & $<$ lliagá> 'wood' \\
\hline \multirow[t]{2}{*}{$/ \mathrm{w} /$} & $<\mathrm{gu}>$ & $<\mathrm{qu}>$ & $<\mathrm{u}>$ & $<\mathrm{hu}>$ \\
\hline & <guexé> 'church' & $<$ tieonquasá $>$ 'fall' & $<$ tabaueré $>$ 'tobacco' & $<$ huillé> 'afternoon' \\
\hline
\end{tabular}

Table 4. Orthographic representation of Elotepec Zapotec consonants

Given that the number of Elotepec forms containing coronal fricatives is relatively small and in view of the variety of the orthographic solutions, interpreting the surface phonetics of the spellings necessitates a comparative approach. A comparison of the Elotepec forms with their cognates in Zaniza and Texmelucan Zapotec makes it likely that Elotepec Zapotec distinguishes coronal fricatives at three places of articulation (see the examples in Table 5). 


\begin{tabular}{|c|c|c|c|}
\hline ELOTEPEC ZAPOTEC & ZANIZA ZAPOTEC & TEXMELUCAN ZAPOTEO & \\
\hline$/ \mathrm{s} /$ & $/ \mathrm{s} /$ & $/ \mathrm{s} /$ & \\
\hline /-sil-/ & $/ \mathrm{siK} /$ & $/ \operatorname{sii} K /$ & 'breakfast' \\
\hline /nisi/ & /nis/ & /nis/ & 'water' \\
\hline$|z|$ & $|z|$ & $|z|$ & \\
\hline /zede/ & /zed/ & /zed/ & 'salt' \\
\hline /uzé/ & $/ \mathrm{uz} /$ & $/ \mathrm{uz} /$ & 'father, priest' \\
\hline $\mid \mathrm{g} /$ & $\mid \mathrm{g} /$ & $\mid \mathrm{g} /$ & \\
\hline /Sopa/ & / Jup/ & / Juup/ & 'six' \\
\hline /kus gife/ & /kuș gij/ & /kut Jij/ & 'wild boar' \\
\hline$|3|$ & $|3|$ & $|3|$ & \\
\hline /dzuze/ & /dzuz/ & /njooz/ & 'God' \\
\hline /gize/ & /giz/ & |jiz/ & 'straw' \\
\hline $\mid \mathrm{s} /$ & $\mid \mathrm{s} /$ & $\mid \mathrm{t} \mathrm{j} /$ & \\
\hline /sona/ & /şun/ & /t fon/ & 'three' \\
\hline /gisi// & /gis/ & /yitf/ & 'hair' \\
\hline$|\mathrm{z}|$ & $|z|$ & $/ \mathrm{d}_{3} /$ & \\
\hline /zize/ & $\mid$ zizl & /dziidz/ & 'coati' \\
\hline /weze/ & /ju' wezl & /ju' wedz/ & 'church' \\
\hline
\end{tabular}

Table 5. Elotepec Zapotec fricatives

Another area in which the Peñafiel vocabulary apparently provides a less than accurate representation of the data are word-initial sequences consisting of a lenis stop preceded by a homorganic nasal. While the pre-stop nasals are not written in the Elotepec responses, their existence in these forms is likely in view of the cognates shown in Table 6 and the description in Rendón (1971), as well as the forms <mbetche> 'people' and <ngo > 'egg' cited in the same publication (Rendón 1971: 216, 224, 225). Based on the evidence of their cognates in Zaniza and Texmelucan Zapotec, it is likely that the last two forms in Table 6, <niaré $>$ /nare/ 'husband' and $<$ nierrieñá> /nerjena/ 'neck', derive their initial $/ \mathrm{n} / \mathrm{s}$ from the earlier (or underlying) sequence [ng'].

\begin{tabular}{|l|l|l|l|}
\hline ELOTEPEC ZAPOTEC & ZANIZA ZAPOTEC & TEXMELUCAN ZAPOTEC & \\
\hline$<$ beché $>$ & $/ \mathrm{mbet} /$ & $/ \mathrm{mbec} /$ & 'people' \\
\hline$<$ biz $>$ & $/ \mathrm{mbiz} /$ & $/ \mathrm{mbiz} /$ & 'finger' \\
\hline$<$ go $>$ & $/ \mathrm{ggu} /$ & $/ \mathrm{gguu} /$ & 'egg' \\
\hline$<$ niaré $>$ & $/ \mathrm{gge} /$ & $/$ jJee/ & 'husband' \\
\hline$<$ nierrieñá $>$ & $/ \mathrm{ger}$ jej/ & $/$ Jerjen/ & 'throat' \\
\hline
\end{tabular}

Table 6. Initial nasal-stop sequences in Elotepec Zapotec

Both Zaniza and Texmelucan Zapotec display stress-conditioned split of Proto-Zapotec *t' (Operstein 2012) which has produced the tap in pretonic contexts, including at the end of initial members of compounds, and a palatal obstruent in posttonic contexts (see Table 7). The presence in the Peñafiel vocabulary of forms like /riti/ 'bone' (spelled $<$ riti $>$ ), /rene/ 'blood' ( $<$ reñié $>$ ) and $/ \mathrm{ru} /$ 'mouth' (in $<$ runá $>$ ), on the one hand, and of /gedze/ 'seven' (spelled $<$ gueché $>$ ), on the other, along with forms like $<$ ru $>$ 'mouth', $<$ ree $>$ 'jug' $(<*$ t'e?e), $<$ nichi $>$ 'milk' $(<*$ ni:?t'i?) and 
$<$ richi $>$ 'laugh' $\left(<*^{*}\right.$-xit'i) reported in Belmar (1901), appear to point to the same types of outcomes of Proto-Zapotec *t' in Elotepec Zapotec.

\begin{tabular}{|c|c|c|c|c|}
\hline & \multicolumn{2}{|c|}{ PRETONICALLY } & \multicolumn{2}{|c|}{ POSTTONICALLY } \\
\hline PROTO-ZAPOTEC & ZANIZA & TEXMELUCAN & ZANIZA & TEXMELUCAN \\
\hline *t'o?wa 'mouth' & $/ \mathrm{ru} / /$ & $/ \mathrm{ru}^{\prime} /$ & & \\
\hline *t'ene 'blood' & /ren/ & /ren/ & & \\
\hline *kat'i 'seven' & & & $/ \operatorname{gadz} /$ & /gaj/ \\
\hline *kko?t'V(k) 'leg, thigh' & & & $/ \mathrm{k}^{\mathrm{w}} \mathrm{idz} /$ & $/ \mathrm{k}^{\mathrm{w}} \mathrm{iij} /$ \\
\hline *ke:Pt'u 'hole' & /ger-/ & /уег-/ & /gedz/ & /„еej/ \\
\hline *lart'i? 'center of emotions' & /lar-/ & /lar-/ & /ladz/ & /laj/ \\
\hline
\end{tabular}

Table 7. Stress-conditioned split of Proto-Zapotec *t' in Zaniza and Texmelucan Zapotec

The Peñafiel vocabulary contains Elotepec cognates to several of the Zaniza and Texmelucan Zapotec nouns that display stress-conditioned allomorphy depending on whether the noun is used as a free form or as an initial member of a compound (cf. the words for 'hole' in Table 7). The Elotepec word for 'heart, breast' $(<$ lere $>$ ) unexpectedly shows a tap in the free form, and so does the word for 'leg, thigh' (<cuir(án)>), for which this is the only form recorded (see Table 8). A potential explanation for the tap outcome in these forms is generalization of the corresponding pretonic allomorphs.

\begin{tabular}{|c|c|c|c|}
\hline ELOTEPEC & ZANIZA & TEXMELUCAN & \\
\hline 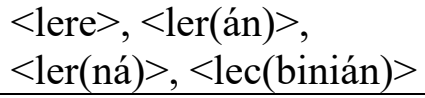 & $/ \operatorname{lad} 3 / \sim / 1 a r-/$ & /laj/ /lar-/ & 'heart, breast' \\
\hline$<$ nierr(ieñá) $>$ & $/$ gedz/ $\sim /$ ger $-/$ & /与eef/ / Jer-/ & 'hole' \\
\hline$<$ ur(loná) $>,<\operatorname{ur}($ sá) $>$ & /udz/ /ur-/ & /uuf/ /ur-/ & 'fruit; pit, stone, seed' \\
\hline$<$ berlabá $>$ & /bidz $/ \sim /$ bir- $/ \sim /$ ber- $/$ & /bij/ /bir-/ & 'frog; toad' \\
\hline
\end{tabular}

The orthography of the Peñafiel vocabulary reflects place assimilation in nasals, as seen in the variable spelling of the prefixes in (2).

$$
\begin{array}{llll}
<\text { enhili }> & \text { 'big' } & <\text { eññan }> & \text { 'red' } \\
<\text { encuenébiniá }> & \text { 'girl' } & <\text { embedo }> & \text { 'child' }
\end{array}
$$

Several Elotepec words in the Peñafiel vocabulary contain final consonants not found in their cognates in Zaniza or Texmelucan Zapotec, or in the corresponding forms collected by Belmar (1901) (see Table 9). The source of these consonants and their function, if any, are unclear, and their presence clashes with the strong tendency that is otherwise seen in the Elotepec responses to end words in vowels, cf. the paragogic [e] in the Spanish loanword /dzuze/ 'God' ( $<$ Sp. dios). There are also unexplained coda consonants in <zecto> 'far' and <zosná> 'three', unless these are merely typographical errors for $<$ zeeto $>$ and <zoná>, respectively (cf. /zet/, /sun/ in Zaniza and /zet/, /t fon/ in Texmelucan Zapotec). ${ }^{6}$

\footnotetext{
${ }^{6}$ A reviewer suggests that the final $<\mathrm{c}>$ may represent a glottal stop or checked vowel.
} 


\begin{tabular}{|c|c|c|c|c|}
\hline ELOTEPEC (PEÑAFIEL) & ELOTEPEC (BELMAR) & ZANIZA & TEXMELUCAN & \\
\hline$<$ chís $>$ & $<$ chii $>$ & $/ \mathrm{t} \mathrm{i} /$ & $/ \mathrm{tii} /$ & 'ten' \\
\hline$<$ beigidebesinnís $>$ & $<$ beguitbiziñe $>$ & /be'jgid bizin/ & /bijid/,/bzin/ & 'bat' \\
\hline$<$ guinec $>$ & $<$ uñie $>$ & /une/ & /gunẽ/ /guanẽ/ & 'scorpion' \\
\hline$<$ chumdec $>$ & $<$ chuun $>$ & /t fup/ & $/ \mathrm{cu} /$ & 'who' \\
\hline$<$ esquinloyec $>$ & & /sigin/ & /t fijip/ & 'bird' \\
\hline$<$ gansex $>$ & & & & 'goose' \\
\hline
\end{tabular}

Table 9. Final consonants in Elotepec Zapotec

\section{Elotepec Zapotec vowels}

The vowel qualities represented in the responses to the Peñafiel questionnaire comprise /a e i o $\mathrm{u} /$. The description of Elotepec Zapotec vowels in Belmar (1901: 4) confirms the existence of five vowel qualities, while Rendón (1971: 216) tentatively adds an [ $\varepsilon$ ] ("probablemente $E$, palatalbaja-abierta" [probably $E$, palatal-low-open]), and uses it in his transcription of the word $<1$ Ere $>$ 'heart'. Variation in the spelling of what appears to be underlying /i/ in the linking element $<$ bi $>$ $\sim<$ rebi $>$ in numerals, and in pretonic syllables elsewhere, points to surface variation in the realization of this vowel (see 3 ). The same inference may be drawn from comparing the transcriptions of one of the animacy-marking prefixes in different sources: while Rendón (1971) transcribes it with $<\mathrm{i}>\left(<\mathrm{i}^{1} \mathrm{SSki}^{3} \tilde{\mathrm{n}} \mathrm{i}>\right.$ 'bird'), in the Peñafiel vocabulary it is transcribed with $<\mathrm{e}>$ (<esquinloyec $>$ 'bird', <ezquiegué $>$ 'fly').

$$
\begin{aligned}
& <\text { chibitubi> 'eleven' <chibechopa> 'twelve' } \\
& <\text { quionrebichí> 'seventy' <galrebechí> 'thirty' } \\
& <\text { bixinñí }>\quad \text { 'mouse' }<\text { beigidebesinnís }>\text { 'bat' } \\
& <\text { yta quieyé }>\quad \text { 'snow' <heita illi }>\quad \text { 'stone, rock' } \\
& <\text { heitaquibiora }>\text { 'gold' }
\end{aligned}
$$

The vowels in the Peñafiel vocabulary are usually spelled $<\mathrm{a}, \mathrm{e}, \mathrm{i}, \mathrm{o}, \mathrm{u}>$; in several cases, a silent $\langle\mathrm{h}\rangle$ is added before the vowel in a word- or morpheme-initial position. Outside the variation shown in (3) above, word-initial /i/ is consistently spelled by means of $<y>$; wordfinally, it is spelled with $<$ iy $>$ about three times (see Table 10). The spellings $<\mathrm{i}>/<$ hi $>$ and $<\mathrm{u}>/<\mathrm{hu}>$ are also used for the palatal and labial glide, respectively, while $<\mathrm{i}>/<\mathrm{e}>$ and $<\mathrm{u}>$ also serve as markers of palatalization and labialization, respectively (see $4 a-b)$. 


\begin{tabular}{|c|c|c|c|}
\hline$/ \mathrm{a} /$ & $<$ baláá $>$ & [bala] & 'meat' \\
\hline \multirow[t]{2}{*}{$/ \mathrm{o} /$} & $<$ obá $>$ & [oba] & 'corn' \\
\hline & $<$ dó $>$ & [do] & 'sea' \\
\hline \multirow[t]{2}{*}{$/ \mathrm{u} /$} & $<\underline{\text { uxxé }}>$ & [uze] & 'priest' \\
\hline & $<$ huniyá $>$ & [unija] & 'to speak' \\
\hline \multirow[t]{2}{*}{$/ \mathrm{e} /$} & $<\overline{\text { beché }}>$ & {$\left[(\mathrm{m})\right.$ bet $\left.\int \mathrm{e}\right]$} & 'people' \\
\hline & $<$ hervezná $>$ & [erbezna] & 'to chirp' \\
\hline \multirow[t]{4}{*}{$/ \mathrm{i} /$} & $<$ bixinñ̄íi $>$ & [bizini] & 'mouse' \\
\hline & $<$ enhili $>$ & [enili] & 'big' \\
\hline & $<$ ynchí $>$ & [indzi] & 'Indian' \\
\hline & $<$ viy $>$ & [bi] & 'wind' \\
\hline
\end{tabular}

Table 10. Elotepec Zapotec vowel qualities and their spelling

(4a)

$\begin{array}{ll}\frac{\text { Palatal glide }}{<\text { quibiagá }>} & \text { 'axe' } \\ <\text { hianá }> & \text { 'hand, arm' }\end{array}$

(4b)

\begin{tabular}{ll} 
Palatal(ized) & consonants \\
\hline <guieté> & 'squash' \\
< leagá $>$ & 'leaf' \\
$<$ reñié> & 'blood'
\end{tabular}

$\underline{\text { Labial glide }}$

$<$ tabaueré> 'tobacco'

$<\underline{\text { huillé}>}$ 'afternoon'

Other features of the Elotepec Zapotec vowel system reflected in the Peñafiel vocabulary include nasality, laryngealization and (phonetic) length. The existence of length and vowel nasality was noted by Belmar, who stressed that these features are especially associated with /a/. Intriguingly, Belmar's description also mentions a "very short è":

El papabuco tiene las mismas vocales que el castellano, esto es $a, e, i, o, u$, pero tiene una $\hat{a}$, nasal y una $\grave{e}$, brevísima que casi se pierde en la pronunciación. Estas vocales se duplican pero muy especialmente la $a$. (Belmar 1901: 4) ${ }^{7}$

Rendón (1971: 216) makes no mention of vowel length but notes the existence of laryngealization: "Además de estas vocales simples, encontramos una serie de rearticuladas que llevan cierre glotal suave intermedio" [In addition to these simple vowels we find a series of rearticulated ones which have a gentle glottal catch in the middle]). Rendón mentions vowel nasalization as well but is unsure of its status: "únicamente la encontramos en ambientes nasales y al final de nombres poseídos y de verbos que se refieren a la primera persona del singular" [we find it only in nasal contexts and at the end of possessed nouns and verbs that refer to the first person singular] (p. 217). The compiler of the Peñafiel vocabulary marks nasality by means of a $<\mathrm{n}>$ after, more rarely both before and after, the vowel; length by repeating the vowel; and laryngealization by means of an $<\mathrm{h}>$ between two identical vowels, ${ }^{8}$ and possibly also by

\footnotetext{
7 "Papabuco has the same vowels as Spanish, that is $a, e, i, o, u$, but it also has a nasal $\hat{a}$ and a very short $e$ which is almost lost in the pronunciation. These vowels may be doubled, especially the $a$."

${ }^{8}$ The use of $<\mathrm{VhV}>$ for representing laryngealized vowels has a long history in Zapotec writing (cf. Smith Stark 2003: 209-210).
} 
repeating the vowel (see Table 11). The laryngealization contrast is directly reflected in the minimal pair <yú> 'earth' / <yuhu> 'house'. Vowel length and nasalization apparently co-occur when a vowel-final stem is followed by the first-person singular clitic pronoun /-ã/ (see, e.g., the words '(my) ear', '(I) walk' and '(I) stand (up)' in Table 11).

\begin{tabular}{|c|c|c|c|}
\hline$<$ ruu $>$ & [ru:] & 'you (sg.)' & \multirow[t]{2}{*}{ LENGTH } \\
\hline$<$ naá $>$ & [na:] & 'today' & \\
\hline <encaá> & [enka'] & 'sky-blue' & \multirow[t]{3}{*}{ LARYNGEALIZATION } \\
\hline$<$ yuhú $>$ & {$\left[\mathrm{ju}^{\prime}\right]$} & 'house' & \\
\hline$<$ enmihi $>$ & [enmi'] & 'small' & \\
\hline$<$ eññan $>$ & [enjã] & 'red' & \multirow[t]{8}{*}{ NASALIZATION } \\
\hline$<$ aan $>$ & [ã:] & 'I' & \\
\hline$<$ ydagaán $>$ & [idagã:] & '(my) ear' & \\
\hline$<$ binián $>$ & [bijã] & '(my) wife' & \\
\hline$<$ usanré> & [uzãre] & '(my) father' & \\
\hline$<$ ysoban $>$ & [izobã] & '(I) sit down' & \\
\hline$<$ zanán $>$ & [zã:] & '(I) walk' & \\
\hline$<$ guasonón $>$ & [wasõ:] & '(I) stand (up)' & \\
\hline
\end{tabular}

A puzzling feature of the Peñafiel orthography is the acute accent mark on most final vowels. According to Rendón (1971: 217), Elotepec words of more than one syllable are generally stressed on the penult; accordingly, in such words the accent mark does not show the location of stress. The same conclusion applies to words in which the accent mark is placed on a clitic, such as the deictic <-ré> or the enclitic first person pronouns <-án> and <-ná>. The location of the accent mark coincides with that of stress only in certain types of words, such as monosyllabics, compounds whose final constituents are monosyllabic, and disyllabic words begining with a prefix (see Table 12). Though it is possible that in some of the words the acute accent indicates tone (according to Rendón 1971: 216, Elotepec Zapotec has four contrastive tones and a "posible tono neutro"), such interpretation would leave open the question of why the tones on all other vowels, including stressed vowels, are ignored. In the absence of a clear indication for its function, the acute accent mark on final vowels may perhaps be interpreted as an orthographic flourish that helps to mark the end of a word.

\begin{tabular}{|l|l|l|l|}
\hline \multicolumn{2}{|c|}{ ACUTE ACCENT MARK COINCIDES } \\
WITH THE PRESUMED LOCATION OF STRESS
\end{tabular}

Table 12. Acute accent mark in the Peñafiel vocabulary

Zapotec languages vary with respect to their treatment of unstressed final vowels, with some varieties keeping them intact and others displaying various degrees of weakening (Uchihara 2016). The Papabuco languages display the full range of possibilities in this regard: while in the Peñafiel vocabulary the final vowels are generally kept, at least in standalone forms, in 
Texmelucan Zapotec they are lost and in Zaniza Zapotec they neutralize to an [a]-quality vowel in citation and pre-pausal forms and are dropped elsewhere (see Table 13).

\begin{tabular}{|c|c|c|c|}
\hline ELOTEPEC & ZANIZA & TEXMELUCAN & \\
\hline$<$ uxé $>$ & {$[\mathrm{uza}] \sim[\mathrm{uz}]$} & [uz] & 'father, priest' \\
\hline$<$ ledé $>$ & {$[$ lada $] \sim[$ lad $]$} & [lad] & 'bark' \\
\hline$<$ quieté $>$ & {$[$ geta $] \sim[$ get } & [jet] & 'squash' \\
\hline$<$ nisi $>$ & {$[$ nisa $] \sim[$ nis $]$} & [nis] & 'water' \\
\hline$<$ riti $>$ & {$[$ rita $] \sim[$ rit $]$} & [rit] & 'bone' \\
\hline$<$ bixinñí $>$ & [bizina] $\sim$ [bizin] & [bzin] & 'mouse' \\
\hline$<$ obá $>$ & {$[\mathrm{uba}] \sim[\mathrm{ub}]$} & [uub] & 'corn' \\
\hline$<$ leagá $>$ & {$[$ Kaga $] \sim[$ Kag $]$} & [Kag] & 'leaf' \\
\hline$<$ guiagua $>$ & {$[$ dzaawa $] \sim[$ dzaaw $]$} & [joow] & 'river' \\
\hline$<$ beco $>$ & {$\left[\right.$ beh $\left.^{\mathrm{w}} \mathrm{a}\right] \sim\left[\mathrm{beh}^{\mathrm{w}}\right]$} & -- & 'dog' \\
\hline
\end{tabular}

Table 13. Posttonic vowels in Papabuco languages

Several kinds of evidence point to the ongoing weakening of posttonic vowels in Elotepec Zapotec as well. For example, the Peñafiel vocabulary contains a mere handful of words with an unstressed final /o/ or /u/, limiting the productive inventory of posttonic vowels to /a/, /e/ and /i/. In several Spanish loans, the unstressed final vowel has been adapted as [e] (see 5). This fact, along with the use of [e] as a paragogic vowel in the loan noun $<$ chuyé $>/$ dzuze/ 'God' $(<\mathrm{Sp}$. dios), argues for the default status of word-final [e] in Elotepec Zapotec, a state of affairs reminiscent of posttonic vowel neutralization in Zaniza Zapotec (see Table 13).

\begin{tabular}{|c|c|c|}
\hline Spanish & Elotepec Zapotec & \\
\hline soltero & $<$ solteré $>$ & 'young (man)' \\
\hline tabaco & $<$ tabaueré $>$ & 'tobacco' \\
\hline tiempo & $<$ tiemné $>$ & 'time' \\
\hline flecha & $<$ fleche essón $>$ & 'arrow' \\
\hline ganso & $<$ gansex $>$ & 'goose' \\
\hline dios & $<$ chuyé $>$ & 'God' \\
\hline
\end{tabular}

Several forms in the Peñafiel vocabulary have two allomorphs distinguished by the presence versus absence of the posttonic vowel. The full forms typically appear as standalone responses to the Spanish prompts whereas the vowelless forms are found, e.g., before clitics or second constituents of compounds (see Table 14). Preservation of the stressed final vowel in the noun 'stone, rock' in (6), in spite of its use as the initial member of several compounds, confirms that only unstressed vowels are subject to deletion in this environment. 


\begin{tabular}{|c|c|c|}
\hline & FULL FORM & VOWELLESS FORM \\
\hline 'twenty' & $\begin{array}{l}\text { [gala] } \\
<\text { galá> 'twenty' }\end{array}$ & $\begin{array}{l}\text { [gal] } \\
<\text { galrebechí> 'thirty' }\end{array}$ \\
\hline 'leaf, grass' & $\begin{array}{l}{[\text { Kaga }]} \\
<\text { leagá> 'leaf' }\end{array}$ & $\begin{array}{l}{[\text { Kag }]} \\
<\text { liagré> 'grass' }\end{array}$ \\
\hline 'father, priest' & $\begin{array}{l}{[\text { uze] }} \\
<\text { uxé> 'priest' }\end{array}$ & $\begin{array}{l}{[\mathrm{uz}]} \\
<\text { usanré> '(my) father' }\end{array}$ \\
\hline 'iron, metal' & $\begin{array}{l}\text { [gibe] } \\
<\text { quis quibé> 'knife' }\end{array}$ & $\begin{array}{l}\text { [gib] } \\
<\text { quibiagá> 'axe' }\end{array}$ \\
\hline 'head' & $\begin{array}{l}\text { [iki] } \\
<\text { quisiquí> 'hair' }\end{array}$ & $\begin{array}{l}{[\mathrm{ik}]} \\
<\text { ycanré> '(my) head' }\end{array}$ \\
\hline 'hair' & $\begin{array}{l}\text { [gisi] } \\
<\text { quisiruná }>\text { 'beard' }\end{array}$ & $\begin{array}{l}\text { [gis] } \\
<\text { quisiquí' 'hair' }\end{array}$ \\
\hline 'big' & $\begin{array}{l}\text { [ili] } \\
<\text { enhili> 'large' }\end{array}$ & $\begin{array}{l}{[\text { ill }]} \\
<\text { bisilná> 'thumb', <cuiillé> 'star' }\end{array}$ \\
\hline
\end{tabular}

Table 14. Posttonic vowel loss in Elotepec Zapotec

(6)
$<$ yta quieyé>
'snow'
(lit. 'stone rain')
$<$ heita illi $>$
'hail'
(lit. 'stone large')
$<$ heitaquibiora $>$ 'gold'
(lit. 'stone metal gold')

In its gradual, conditioned loss of posttonic vowels Elotepec Zapotec shows greater affinity with Zaniza than with Texmelucan Zapotec. The two languages also appear to show affinity in their preservation and gradual weakening of pretonic vowels, as seen in colonial-era borrowings from Spanish (illustrated in Tables 15 and 16, respectively).

\begin{tabular}{|l|l|l|l|}
\hline ELOTEPEC & ZANIZA & TEXMELUCAN & \\
\hline$<$ bixinñí $>$ & $/ \mathrm{bizij} /$ & $/ \mathrm{bzij} /$ & 'mouse' \\
\hline$<$ billisí $>$ & $/$ biziz/ & $/$ bdzidz/ & 'pineapple' \\
\hline
\end{tabular}

\begin{tabular}{|l|l|l|l|}
\hline SPANISH & ELOTEPEC & ZANIZA & \\
\hline tomín & $<$-timienñá $>$ & $/$ timij/ & (type of silver coin) \\
\hline amigo & $<$ ymigaré $>$ & $/ \mathrm{miw} /$ & 'friend' \\
\hline \multicolumn{4}{|c|}{ Table 16. Treatment of pretonic vowels in early Spanish loans }
\end{tabular}

\section{Morphosyntax}

The responses to the Peñafiel questionnaire contain a fair amount of information about the inflection, derivation and syntactic structures of Elotepec Zapotec. They show, for instance, that Elotepec Zapotec has both free-standing and clitic forms of personal pronouns (Table 17), that the clitic forms may be used as subjects of verbs (in 7a) and as possessors of nouns (in 7b), that there is at least one deictic clitic (in 7c), that adjectives occur after the nouns they modify (in 7d) and that the modifying member of a nominal compound follows the head (in 7e). The multiword expressions in (7f) that translate Sp. lloviznar 'to drizzle' and trabajar 'to work' point, 
respectively, to the verb-initial constituent order and the possibility of preverbal placement of nominal objects.

\begin{tabular}{|c|c|c|c|c|c|c|}
\hline & \multicolumn{2}{|c|}{ PEÑAFIEL VOCABULARY } & \multicolumn{2}{|c|}{ BELMAR (1901) } & \multicolumn{2}{|c|}{ RENDÓN (1971) } \\
\hline & FREE & CLITIC & FREE & CLITIC $^{9}$ & FREE & CLITIC \\
\hline $1 \mathrm{SG}$ & $<$ aan $>$ & $<$ an $>\sim<$ án $>$ & $<\hat{\mathrm{a}}>$ & $<\hat{\mathrm{a}}>/<\mathrm{a}>$ & $\mathrm{a}^{3} \mathrm{~N}$ & $(1) \mathrm{a}^{1 / 3} \mathrm{~N}$ \\
\hline $2 \mathrm{SG}$ & $<$ ruú $>$ & $<$ rú $>$ & $<\mathrm{ru}>$ & $<\mathrm{ru}>/<\mathrm{ru}>$ & $\mathrm{ru}^{3}$ & $(1) \mathrm{ru}^{3}$ \\
\hline $3 \mathrm{SG}$ & $<$ yrsé $>$ & $<$ ya $>\sim<$ ia $>$ & $<$ iré $>$ & $<$ ire $>/<$ ya $>$ & $\mathrm{i}^{1} \mathrm{r}^{1} \mathrm{e}$ & $(y) a^{3}$ \\
\hline $1 \mathrm{PL}$ & $<$ biegniá $>$ & $<$ na $>\sim<$ ná $>$ & $<$ cikènana $>10$ & $<$ nîa $>/<$ na $>$ & $\mathrm{bi}^{2} \mathrm{ge}^{1} \mathrm{nna}^{3}$ & $(1) n a^{1 / 3}$ \\
\hline $2 \mathrm{PL}$ & $<$ bigaaná $>$ & -- & $<$ bikèru $>$ & $<$ bkieru $>/<$ ru $>$ & $b^{2} g(i) r u^{3}$ & (1)ru ${ }^{1}$ \\
\hline $3 \mathrm{PL}$ & $<$ bicailié $>$ & -- & <bikìre $>$ & $<$ bikire $>/<$ ya $>$ & $\mathrm{bi}^{2} \mathrm{gi}^{1} \mathrm{re}^{1}$ & $(\mathrm{y}) \mathrm{a}^{1}$ \\
\hline $3 \mathrm{AN}$ & -- & $<-$ má $>$ & -- & -- & -- & -- \\
\hline
\end{tabular}

Table 17. Elotepec Zapotec personal pronouns

(7a) <dezná $>\quad<$ heryimmá $>$

$<$ dez-ná $>\quad<$ heryim-má $>$

sleep-1PL bark-3ANIMAL

'we sleep' 'it barks'

(7b)

$<$ luxná $>\quad<$ cuirán $>$

$<$ lux-ná> <cuir-án>

tongue-1PL leg-1SG

'our tongue' 'my leg'

(7c)

$<$ baré $>\quad<$ ycanré $>$

$<$ ba-ré $>\quad<$ yc-an-ré $>$

'sky-DEICTIC' 'head-1sG-DEICTIC'

'sky' 'my head'

(7d) $<$ heita illi $>\quad<$ bichibalanré $>$

stone large < <ichi bal-an-ré>

'large stone' 'brother old-1SG-DEICTIC',

'my elder brother'

(7e) <quisiquí $>\quad$ tiomgieyé>

$<$ quis iquí $>\quad<$ tiom gieyé $>$

hair head time rain

'(head) hair' 'rain season'

(7f)

$<$ yatiguieyé $>\quad<$ riniricháán $>$

$<$ yati guieyé $>\quad<$ rini rich-áán $>$

fall rain work do-1SG

'it rains' 'I work'

\footnotetext{
${ }^{9}$ The first form in each set is the possessor clitic and the second form is the subject clitic (Belmar 1901: 4-7).
}

${ }^{10}$ A likely typo for $<$ bikèna $>$. According to Belmar (1901: 4-5), <bike $>$ is a plural morpheme. 
From the viewpoint of their morphological makeup, the native noun types comprise monoand disyllabic root nouns, nouns of two or more syllables that contain a prefix, and compounds. Three of the nouns borrowed from Spanish are furnished with what appears to be a suffix (see Table 18).

\begin{tabular}{|l|l|}
\hline TYPE OF NOUN & EXAMPLES \\
\hline Root noun & $\begin{array}{l}<\text { dó> 'sea' } \\
<\text { nisi> 'water' }\end{array}$ \\
\hline Prefixed noun & $\begin{array}{l}<\text { ygalá> 'old (man)' } \\
<\text { bixinñí> 'mouse' } \\
\text { <ezquiegué> 'fly' }\end{array}$ \\
\hline Compound & $\begin{array}{l}<\text { yta quieyé> 'snow' (lit. 'stone rain') } \\
\text { <quisiquí> 'hair' (lit. 'hair head') } \\
<\text { bisilná> 'thumb' (lit. 'finger large') }\end{array}$ \\
\hline Spanish loan noun with a suffix & $\begin{array}{l}<\text { jefeson> 'boss' } \\
<\text { tigreson> 'tiger' } \\
\text { <fleche essón> 'arrow' }\end{array}$ \\
\hline
\end{tabular}

Table 18. Structural types of nouns in Elotepec Zapotec

The body-part and kinship terms are typically furnished with a first person clitic pronoun and/or the deictic clitic < ré> (see 8a); the deictic is found on other nouns as well (see 8b). If both types of clitics are present, the pronoun occurs closer to the noun stem (see $8 \mathrm{c}$ ).

\begin{tabular}{|c|c|c|c|}
\hline $\begin{array}{l}<\text { loná }> \\
<\text { cuirán }> \\
<\text { binián }> \\
<\text { bedoré> }\end{array}$ & $\begin{array}{l}\text { /lo-na/ } \\
\text { /k }{ }^{\mathrm{w}} \mathrm{ir}-\tilde{\mathrm{a}} / \\
\text { /bij-ã / } \\
\text { /bedo-re/ }\end{array}$ & $\begin{array}{l}\text { 'face-1PL' } \\
\text { 'leg-1SG' } \\
\text { 'woman-1SG' } \\
\text { 'child-DEICTIC' }\end{array}$ & $\begin{array}{l}\text { 'our face' } \\
\text { 'my leg' } \\
\text { "my wife' } \\
\text { child' }\end{array}$ \\
\hline $\begin{array}{l}<\text { baré> } \\
<\text { canoré }>\end{array}$ & $\begin{array}{l}\text { /ba-re/ } \\
\text { /kano-re/ }\end{array}$ & $\begin{array}{l}\text { 'sky-DEICTIC' } \\
\text { 'trough-DEICTIC' }\end{array}$ & $\begin{array}{l}\text { 'sky' } \\
\text { 'trough' }\end{array}$ \\
\hline $\begin{array}{l}\text { <ycanré> } \\
\text { <usanré> }\end{array}$ & $\begin{array}{l}\text { /ik-ã-re/ } \\
\text { /uz-ã-re/ }\end{array}$ & $\begin{array}{l}\text { 'head-1SG-DEICTIC' } \\
\text { 'father-1SG-DEICTIC }\end{array}$ & $\begin{array}{l}\text { 'my head' } \\
\text { 'my father' }\end{array}$ \\
\hline
\end{tabular}

Identifiable noun prefixes (or proclitics) include animacy markers (see 9a) and what appear to be nominalization markers (see $9 b$ ); the prefix $<$ en $>$ is also used with adjectives (see 9b).

(9a) Animacy markers

$\begin{array}{llll}<\text { bi }>\sim<\text { b }> & & <\text { ez }>\sim<\text { es }> \\ \text { <binián> } & \text { 'woman' } & <\text { ezquiegué> } & \text { 'fly' } \\ <\text { bixinñí> } & \text { 'mouse' } & <\text { ezquincazá> } & \text { 'crow' } \\ <\text { billisí> } & \text { 'pineapple' } & <\text { esquienú> } & \text { 'mosquito' } \\ \text { < brisi }> & \text { 'squirrel' } & <\text { esquinloyec }> & \text { 'bird' }\end{array}$


(9b) Nominalization markers

$\begin{array}{llll}<y>/<\text { en }> & & <\text { en }> \\ \text { <ycuené> } & \text { 'boy' } & <\text { encasá> } & \text { 'black' } \\ \text { <yquieyé> } & \text { 'man' } & <\text { encaá> } & \text { 'sky-blue' } \\ \text { <ygalá> } & \text { 'old (man)' } & \text { <enguesé> } & \text { 'yellow' } \\ \text { <ybana }> & \text { 'thief' } & <\text { enquiné> } & \text { 'green' } \\ \text { <ytó> } & \text { 'dead (person)' } & <\text { eñnan> } & \text { 'red' } \\ \text { <embedo> } & \text { 'child' } & <\text { enmihi> } & \text { 'small' } \\ \text { <encuenébiniá> } & \text { 'girl' } & <\text { enhili> } & \text { 'big' }\end{array}$

Most cardinal numerals above ten are built by using the linking elements $<$ bi $>\sim<$ be $>$ and $<$ rebi $>\sim<$ rebe $>$ (see 10). The element $<$ nala $>$, apparently morphologically related to $<$ galá $>$ 'twenty', functions with the meanings of 'twenty' (in <taabinala > 'eighty-and-twenty', i.e. 'hundred') and 'hundred' (in <chalnalá> 'half-hundred', i.e. 'fifty'). The cognate form in Texmelucan Zapotec has the meaning of 'twenty' in /gajnal/ 'hundred' (lit. 'five-twenty'); the cognate in Zaniza Zapotec has the meaning of 'hundred', both by itself and in / $\mathrm{t}$ al nal/ 'fifty' (lit. 'half-hundred').

\begin{tabular}{|c|c|c|}
\hline$<$ chi-bi-tubi $>$ & ' 10 -and-1' & $=$ \\
\hline$<$ chi-be-chopa $>$ & '10-and-2' & $=$ \\
\hline <gal-rebe-chí> & '20-and-10' & $=$ \\
\hline$<$ chal-nalá $>$ & 'half-100' & $=$ \\
\hline$<$ quion-rebi-chí $>$ & '60-and-10' & $=$ \\
\hline$<$ taa-bi-chí $>$ & '80-and-10' & $=$ \\
\hline taa-bi-nala> & '80-and-20' & $=$ \\
\hline
\end{tabular}

Both Zaniza and Texmelucan Zapotec morphologically distinguish five TAM categories: potential, habitual, completive, irrealis and stative/continuative (Speck 1978: 26-28; Operstein 2015a: 28ff). The Peñafiel vocabulary contains a sufficient number of verb forms in its responses to identify four of these in Elotepec Zapotec (see Table 19).

\begin{tabular}{|c|c|c|c|}
\hline POTENTIAL & HABITUAL & COMPLETIVE & STATIVE/CONTINUATIVE \\
\hline $\begin{array}{l}<\underline{\text { hi-ñi-na }>} \\
\text { 'we will speak' }\end{array}$ & $\begin{array}{l}<\text { her-yím-má> } \\
\text { 'it barks' }\end{array}$ & $\begin{array}{l}<\underline{\text { hu-ni-yá }>} \\
\text { 'he spoke' }\end{array}$ & $\begin{array}{l}<\text { yati guieyé> } \\
\text { 'it rains' }\end{array}$ \\
\hline $\begin{array}{l}<y-\text { sob-an }> \\
\text { 'I will sit down' }\end{array}$ & $\begin{array}{l}<\text { ni er-sob ru-yá> } \\
\text { 'which he puts in his mouth' }\end{array}$ & & \\
\hline $\begin{array}{l}<\text { dau-na }> \\
\text { 'we will eat' }\end{array}$ & $\begin{array}{l}<\underline{r}-a u-r u ́> \\
\text { 'you eat' }\end{array}$ & & \\
\hline
\end{tabular}

Texmelucan and Zaniza Zapotec both possess a substantial number of verbs in which the stem used with first-person subjects differs from the one used with second- and third-person subjects (Speck 1978: 37; Operstein 2002: 53-54, 2015a: 55, 2017a). The practice of the Peñafiel

\footnotetext{
${ }^{11}$ The English glosses reflect the morphological makeup of the Zapotec responses rather than the corresponding Spanish prompts.
} 
questionnaire's respondent to supply many of the Spanish verbs with first-person subjects in his transations provides us with valuable information about this type of suppletion in Elotepec Zapotec. The form <raurú $>$ 'you eat', an apparently erroneous response to the Spanish prompt correr 'to run', supplies direct confirmation of the existence of this suppletion type in Elotepec Zapotec in view of the respose $<$ dauna $>$ 'we eat' to the prompt comer 'to eat' (see Table 20).

\begin{tabular}{|c|c|c|c|c|c|c|}
\hline \multicolumn{2}{|c|}{ ELOTEPEC } & \multicolumn{2}{|c|}{ ZANIZA } & \multicolumn{2}{|c|}{ TEXMELUCAN } & \\
\hline 1 person & $2 / 3$ person & 1 person & $2 / 3$ person & 1 person & $2 / 3$ person & \\
\hline$<$ dauna $>$ & <raurú> & /daw/ & /aw/ & /daw/ & $/ 0 /$ & 'eat' \\
\hline$<$ diena $>$ & & $/ \mathrm{do}^{\prime} /$ & $/ 0^{\prime} /$ & $/ \mathrm{do}^{\prime} /$ & $/ 0^{\prime} /$ & 'drink' \\
\hline $\begin{array}{l}<\text { dalná }>\text {, } \\
<\text { dalruná }\end{array}$ & & /dul/ & /ul/ & /dul/ & /ul/ & $\begin{array}{l}\text { 'dance', } \\
\text { 'sing' }\end{array}$ \\
\hline$<$ dezná $>$ & & /das/ & /as/ & /das/ & /aas/ & 'sleep' \\
\hline$<$ dutaní $>$ & & /dut/ & /ut/ & /dut/ & /ut/ & 'kill' \\
\hline$<$ yapaán $>$ & & /jap/ & /jed/ & /jap/ & /jed/ & 'come' \\
\hline
\end{tabular}

Table 20. Suppletive first-person verb forms in Elotepec Zapotec

\section{Spanish loanwords}

Twenty-two responses in the Peñafiel vocabulary contain nouns borrowed from Spanish. Several of the borrowings have an added suffix or final consonant (see 11b) and several more occur in hybrid compounds that combine Zapotec and Spanish material (see 11c). The words for 'friend', 'tobacco', 'trough' and, possibly, 'time' are supplied with a deictic. In percentage terms, the lexical items built in whole or in part on Spanish-derived items constitute about $9 \%$ of the total.

\section{Spanish prompt}

Elotepec response

dios

indio

amigo

soltero

tortuga

$<$ chuyé>

$<$ ynchí>

$<$ ymigaré>

$<$ solteré $>$

paloma

pato

villa

canoa

tabaco

pipa

mil

tiempo

$<$ tortuga $>$

$<$ uraga $>$

$<$ badá $>$

$<$ villi $>$

$<$ canoré $>$

$<$ tabaueré>

$<$ barril ó cachimba $>$

$<$ mil $>$

$<$ tiemné $>$
'God'

'Indian'

'friend'

'young (man)'

'turtle'

'dove'

'duck'

'villa'

'trough'

'tobacco'

'pipe'

'thousand'

'time'
$(<$ urraca $)$

( $<$ barril, cachimba)

(11b)

$\begin{array}{lll}\text { jefe } & <\text { jefeson }> & \text { 'boss' } \\ \text { tigre } & <\text { tigreson }> & \text { 'tiger' } \\ \text { flecha } & <\text { fleche essón }> & \text { 'arrow' } \\ \text { ganso } & <\text { gansex }> & \text { 'goose' }\end{array}$




$\begin{array}{llll}\text { (11c) plata } & <\text { guibitimienñá> } & \text { 'silver, money' } & (<\text { tomín }) \\ \text { jabalí } & <\text { cusquillé }> & \text { 'wild boar' } & (<\text { cuche }) \\ \text { primavera } & <\text { tiomgieyé> } & \text { 'spring' } & (<\text { tiempo }) \\ \text { otoño } & <\text { tieonquasá }> & \text { 'fall' } & (<\text { tiempo }) \\ \text { verano } & <\text { tieomerrubiy }> & \text { 'summer' } & (<\text { tiempo })\end{array}$

The phonological shape of several of the loans betrays an early date of borrowing. For $<$ chuyé> 'God' (< Sp. dios), this inference follows from the adaptation of the Spanish sibilant as a palatal fricative, a common strategy for adapting this sound in early Spanish loans in Latin American indigenous languages (Parodi 1995, 2017; Smith Stark 2007; Operstein 2016, 2017b). This type of adaptation is not apparent in <solteré> 'young (man)' or <gansex $>$ 'goose', which thus appear to have been borrowed more recently. For $<$ chuyé $>$ 'God' and <ynchí $>$ 'Indian' ( $<$ Sp. indio), an early date of introduction may additionally be inferred from the adaptation of the sequence $/ \mathrm{dj} /$. As seen in Table 21, in the early loan dios all Papabuco languages reflect this sequence in the same way as Proto-Zapotec *t' (Operstein 2005: 110-111, 2012: 8-9) whereas in more recent loans it is borrowed unchanged, cf. Texmelucan /radjo/ ( $<\mathrm{Sp}$. radio), Zaniza /djeg/ ( $<$ Sp. Diego (name)). The early date of borrowing of $<$ cus- $>$ 'pig' $(<\mathrm{Sp}$. cuche) is suggested by deaffrication of the Spanish affricate: this treatment contrasts with the absence of deaffrication in what are apparently later loans < cachimba $>$ 'pipe' ( $<$ Sp. cachimba) and $<$ fleche essón $>$ 'arrow' $(<$ Sp. flecha). Deaffrication of $/ \mathrm{t} / /$ in this loan indicates that the Spanish affricate was initially adapted with the native fortis affricate (see Table 21). The early date of entry of $<$ badá $>$ 'duck' $(<\mathrm{Sp}$. pato) is suggested by the adaptation of the Spanish voiceless stops as lenis (voiced) rather than fortis (unvoiced); this contrasts with the adaptation of voiceless stops in more recent loans such as <tigreson> 'tiger' and <tortuga $>$ 'turtle'. Other early loans include <ymigaré> 'friend' and <-timienñá $>$ which show raising of pretonic vowels; this treatment contrasts with the lack of pretonic vowel raising in <tortuga $>$ 'turtle' and < solteré $>$ 'young (man)'. A few of the Spanishorigin words appear to be completely unadapted phonologically; these include <tortuga > turtle', $<$ mil $>$ 'thousand' and <cachimba $>$ 'pipe'. The remaining borrowings show various degrees of phonological and/or morphological adaptation to the Elotepec structures.

\begin{tabular}{|c|c|c|c|c|c|}
\hline & & TEXMELUCAN & ZANIZA & ELOTEPEC & \\
\hline$/ \mathrm{dj} /$ & Sp. dios & /njooz/ & /dzuz/ & $<$ chuyé> & 'God' \\
\hline$* \mathrm{t}^{\prime}$ & *kat'i & /gaj/ & $/ \operatorname{gad} 3 /$ & <gueché> & 'seven' \\
\hline$/ \mathrm{t} \mathrm{f} /$ & Sp. cuche & /kutg/ & /kus/ & $<\operatorname{cus}($ quillé) $>$ & 'pig' \\
\hline$*$ ttz & ${ }^{*} \operatorname{kittza}(?)$ & /jitg/ & /gis/ & $<$ quis(iquí) > & 'hair' \\
\hline
\end{tabular}

Table 21. Adaptation of Spanish $/ \mathrm{dj} /$ and $/ \mathrm{t} \mathrm{j} /$ in early Spanish loans

\section{Residual issues}

Some of the responses to the Spanish prompts present inconsistencies and apparent orthographical errors, which in some cases may affect the correctness of their interpretation. For example, <zan maré> 'my younger sister' is an apparent typo for <zan miaré>; this inference follows from comparing this entry with $<$ bichimiaré $>$ 'my younger brother', <lechimiré $>$ 'plain' and $<$ enmihi $>$ 'small', and in light of the Zaniza and Texmelucan Zapotec cognate $/ \mathrm{mi}^{\prime}$ ' 'small'. The form <lechilgré> 'valley' is an apparent typo for <lechilré> (i.e. <lech il-ré>), as is 
suggested by the immediately following response <lechimiré> (i.e. <lechi mi-ré>) 'plain': these entries arguably contain as their second elements the adjectives 'large' and 'small', respectively. The response < biltí $>$ 'rabbit' is an apparent typo for $<$ billí $>$ (/bisi $\mathrm{i})$; this inference follows from the cognate forms in Zaniza and Texmelucan Zapotec (/bis/ and /bit J/, respectively) and from Belmar's (1901) form $<$ bisekuliana $>$ 'hare', a compound of $<$ bise $>$ 'rabbit' and $<$ kuliana $>$ 'hare'. The $<\mathrm{t}>$ for $<\mathrm{l}>$ typo is also found in $<$ biti quillé $>$ 'snake' for the intended $<$ bili quillé $>$, in light of the cognate $/ \mathrm{bi} K /$ 'snake' in Zaniza and Texmelucan Zapotec and the immediately following entry, <billesie > 'rattlesnake'. <lumní> 'eight' appears to be a typo for <lluní>, or perhaps $<$ lluñí $>$, since this form is given as $<$ shuñi $>$ by Belmar (1901) and in view of its cognate / Juj/ in Zaniza and Texmelucan Zapotec.

Another orthographic issue is inconsistent representation of the first person singular clitic pronoun /-ãa/: while its nasality is often marked by a following $<\mathrm{n}>$, this tends not to happen when there is an immediately preceding nasal consonant (see 12). Based on Rendón's (1971) observation that in Elotepec Zapotec nasality is found in nasal contexts, I assume that all the forms in (12) contain the first person singular clitic pronoun $/-\tilde{a} /$.

\begin{tabular}{|c|c|}
\hline Nasality marked & Nasality unmarked \\
\hline$<$ bichibalanré $>$ 'my older brother' & $<$ bichimiaré> 'my younger brother' \\
\hline$<$ usanré $>$ 'my father' & $\begin{array}{l}<\text { naré> 'my mother' } \\
<\text { niaré }>\text { 'my husband' } \\
<\text { biniaré > 'my wife' }\end{array}$ \\
\hline
\end{tabular}

A few of the responses contain what appear to be errors. For example, the form $<$ billisí $>$, given in response to the Spanish prompt pino 'pine tree', is clearly cognate with the Zaniza and Texmelucan Zapotec words for 'pineapple' (Sp. piña). The form $<$ bití $>$, given in response to Sp. zorra '(female) fox', is cognate with Zaniza and Texmelucan Zapotec words for 'skunk' (Sp. zorrillo). The form <raurú> 'you eat' (Sp. comer) was apparently given in error in response to Sp. correr 'to run' (see Table 22).

\begin{tabular}{|l|l|l|l|}
\hline SPANISH PROMPT & ELOTEPEC RESPONSE & ZANIZA COGNATE & TEXMELUCAN COGNATE \\
\hline pino 'pine tree' & $<$ billisí'> & /bizizil ' pineapple' & /bdzidz/ 'pineapple' \\
\hline zorra 'fox' & $<$ bití> & /bit/ 'skunk' & /bit/ 'skunk' \\
\hline correr 'to run' & $<$ raurú> & /rawr/ 'you eat' & /ror/ 'you eat' \\
\hline
\end{tabular}

Table 22. Apparent errors in Elotepec responses

Some of the Elotepec responses contain added material that is not found in their cognates in the other Papabuco languages or in the Elotepec forms cited by Belmar (1901) or Rendón (1971). Some of the responses disagree with the Elotepec forms reported in the other sources. An interesting example of the latter are different allomorphs of the numerals 'one' and 'two' depending on whether they are cited in isolation or as part of the numerals 'eleven' and 'twelve': as seen in Table 23, the allomorphy <tibi $>\sim<$ tubi $>$ 'one' and <chabá $>\sim$ $<$ chopa $>$ 'two' is not reported by Belmar (1901) and is not present in the other Papabuco languages. The form $<$ bilñici $>$, given in response to the prompt nombre 'name', may have been influenced by, or perhaps actually given in response to, the immediately preceding entry anguila 'eel' (<bilñici $>$ appears to be composed of < bil $>$ 'snake' and $<$ ñici $>$ 'water'). 


\begin{tabular}{|c|c|c|c|c|c|}
\hline $\begin{array}{l}\text { PEÑAFIEL } \\
\text { VOCABULARY }\end{array}$ & $\begin{array}{l}\text { BELMAR } \\
(1901)\end{array}$ & $\begin{array}{l}\text { RENDÓN } \\
(1971)\end{array}$ & $\begin{array}{l}\text { ZANIZA } \\
\text { COGNATE }\end{array}$ & $\begin{array}{l}\text { TEXMELUCAN } \\
\text { COGNATE }\end{array}$ & \\
\hline$<$ llaegrellé $^{12}$ & $<$ yaga $>$ & $<$ yaga $>$ & /jag/ & /jag/ & 'tree' \\
\hline$<$ balsedé $>^{13}$ & $<$ balla $>$ & $<$ bala $>$ & /bal/ & /bel/ & 'fish' \\
\hline$<$ ticiudán> & $<$ shina $>$ & $<\mathrm{Sa}^{1} \mathrm{~N}>$ & $/ \int \mathrm{i} /$ & $/ \int \mathrm{e} /$ & 'belly' \\
\hline$<$ betbalná $>$ & $<$ balla $>$ & $<\mathrm{ba}^{3} \mathrm{la}>$ & /bal/ & /beel/ & $\begin{array}{l}\text { 'body'/ } \\
\text { 'meat' }\end{array}$ \\
\hline$<$ bilñici $>$ & $<$ laa $>$ & $<\mathrm{la}^{3}>$ & $/ 1 \mathrm{a} /$ & /nu la/ & 'name' \\
\hline$<$ esquinloyec $>$ & & $<\mathrm{i}^{1} \mathrm{SSki}^{3} \tilde{\mathrm{n}} \mathrm{i}>$ & /sigin/ & /tfijij/ & 'bird' \\
\hline$<$ ynquillanré> & $<$ iñi $>$ & & $/ \mathrm{i}^{\prime} \mathrm{p} /$ & $/ \mathrm{i}^{\prime} \mathrm{n} /$ & 'son' \\
\hline$<$ billesie $>$ & & & /biא bisun/ & /biא daab/ & 'rattlesnake' \\
\hline$<$ loxilna $>$ & & & $/ \int \mathrm{i} K /$ & /lowe/ & 'wing'"14 \\
\hline $\begin{array}{l}<\text { yuhu } \\
\text { dusanguaquiyé> }\end{array}$ & & & /ju' giz/ & /ju' Jiz/ & 'thatch hut' \\
\hline $\begin{array}{l}<\text { tibi }> \\
<\text { chibitubi }>\end{array}$ & $\begin{array}{l}<\text { tibi }> \\
<\text { chiirbititibi }>\end{array}$ & & $\begin{array}{l}\text { /tib/, } \\
\text { /tfiribitib/ }\end{array}$ & $\begin{array}{l}\text { /tub/, } \\
\text { /trotub/ }\end{array}$ & $\begin{array}{l}\text { 'one' } \\
\text { 'eleven' }\end{array}$ \\
\hline $\begin{array}{l}<\text { chabá }>, \\
<\text { chibechopa }>\end{array}$ & $\begin{array}{l}<\text { chopa }> \\
<\text { chiirbichopa }>\end{array}$ & & 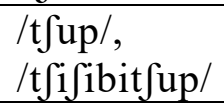 & $\begin{array}{l}\text { /cup/, } \\
\text { /trocup/ }\end{array}$ & $\begin{array}{l}\text { 'two' } \\
\text { 'twelve' }\end{array}$ \\
\hline
\end{tabular}

Table 23. Selected Elotepec responses

Some of the responses to the noun prompts in Spanish consist of verb forms or multiword expressions. For example, the Elotepec translation for Sp. mañana 'morning' is given as $<$ hersilná $>$, which appears to be the habitual aspect form of the verb < <il $>$ with the first person plural subject marker ( $<$ her-sil-na $>$ ); this verb appears to be related to the noun 'breakfast' in Texmelucan Zapotec $(/ \mathrm{sii} K /)$ and Zaniza Zapotec $(/ \mathrm{si} K /)$. The translations for Sp. trueno 'thunder' $(<$ herniquiuxi $>$ ) and relámpago 'lightning' ( $<$ heryiloquixi $>$ ) are also verbal in form and appear to contain the noun meaning 'thunder' (cf. /guzii/ 'thunder', /fi ni guzii/ 'lightning' in Texmelucan Zapotec; /uzi/ 'thunder', / $\mathbf{i}$ lo uzi/ 'lightning' in Zaniza Zapotec). The Elotepec response to Sp. pipa 'pipe' is <niersobruyá>, 'what he puts in his mouth' or, possibly, 'what is in his mouth' (<ni er-sob ru-yá $>$ ). The translation for Sp. caldera 'cauldron', <serupinieyé>, is perhaps analyzable as a place nominalization, <se rupi nieyé> 'where clothes are washed' (cf. /ze'/ 'there', /nedz/ 'clothes' in Zaniza Zapotec; /ze'/ 'there', /nej/ 'clothes' in Texmelucan Zapotec).

Eight of the ten translations for the abstract nouns that round off the Peñafiel questionnaire prove to be challenging (and, perhaps, were so for the respondent). While some contain identifiable morphemes - for example, the $<$ xede $>$ of $<$ becuexedé $>$ 'laziness' is almost certainly the morpheme for 'lazy' (cf. Zaniza/zed/, Texmelucan/zeed/) and the <aan $>$ of $<$ hudimbraán $>$ 'kindness' is the first person singular pronoun clitic - the limited amount of data at our disposal precludes their full analysis at this time. This is also true of the words for the seasons of the year: while the translations for spring (<tiomgieyé>, lit. 'rain time') and fall (<tieonquasá $>$, lit. 'dry time') are transparent, the one for winter (<visgraená $>$ ) is not, and the one for summer $(<$ tieomerrubiy $>$ ) contains an unidentified second element. The translation for guerrero 'warrior', given as $<$ ygqui, eryú $>$, is both phonologically and morphologically unclear.

\footnotetext{
${ }^{12}$ Compare with < guibiagá $>$ 'axe', a compound whose second member $<$ iaga $>$ is the word for tree or wood.

${ }^{13}$ Compare with <zedé> 'salt'.

14 The Zaniza and Texmelucan forms may be cognate with different component parts of the Elotepec form.
} 


\section{Conclusion}

This paper has presented a proposed transcription and a linguistic and orthographic analysis of the Peñafiel vocabulary from San Juan Elotepec. Where applicable, the Peñafiel were evaluated against the other published descriptions of Elotepec Zapotec, Belmar (1901) and Rendón (1971), and compared with cognates from the other Papabuco languages.

The Peñafiel vocabulary reveals that, individual innovations apart, late nineteenth-century Elotepec Zapotec shares more phonological features with present-day Zaniza than Texmelucan Zapotec. The shared similarities include the treatment of unstressed vowels, which are preserved in pretonic position and subjected to conditioned loss in posttonic position; fricativization of Proto-Zapotec *ttz and *tz, which has produced an additional set of coronal fricatives in Elotepec and Zaniza Zapotec as compared to Texmelucan Zapotec; and affrication of ProtoZapotec * $\mathrm{tt}^{\prime}$ and posttonic * $\mathrm{t}^{\prime}$, which continue to retain their stop articulation in Texmelucan Zapotec (see Table 24 below as well as Tables 5, 15 and 16 above). The features that Elotepec Zapotec shares with Texmelucan Zapotec to the exclusion of Zaniza Zapotec include preservation of the stop articulation of medial $* \mathrm{kk}$ and of $* \mathrm{k}$ in the palatalizing environment of *kePla 'lake' (shown in Table 24).

The Spanish loanwords captured by the Peñafiel questionnaire consist of borrowings that are common to all Papabuco languages, such as dios 'God' and amigo 'friend', and those for which present-day Zaniza and Texmelucan Zapotec continue to use inherited words; these include the words for tobacco and turtle. The phonological shape of the borrowings points to at least two chronological layers of Spanish loanwords in Elotepec Zapotec.

In the larger context of Zapotec comparative linguistics, the Peñafiel vocabulary provides valuable evidence from the Papabuco branch of the family relevant to reconstruction of posttonic vowels, and a unique instrument for observing linguistic change in a Zapotec language over the period of more than a century. In light of the critical dearth of published information on Elotepec Zapotec, the Peñafiel vocabulary also helps fill important lacunae in our understanding of this endangered and under-documented language.

\begin{tabular}{|c|c|c|c|c|}
\hline & ELOTEPEC & ZANIZA & TEXMELUCAN & \\
\hline 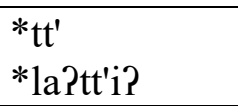 & $\begin{array}{l}<\mathrm{ch}> \\
<\text { lech(ilgré) }>\end{array}$ & $\begin{array}{l}/ \mathrm{t} \int / \\
/ \text { lat } \int /\end{array}$ & $\begin{array}{l}/ \mathrm{c} / \\
/ \mathrm{lac} /\end{array}$ & 'valley' \\
\hline $\begin{array}{l}*_{\mathrm{t}^{\prime}} \\
*_{\text {kat'i }}\end{array}$ & $\begin{array}{l}<\text { ch }> \\
<\text { gueché }>\end{array}$ & $\begin{array}{l}/ \mathrm{d}_{3} / \\
/ \mathrm{gad} /\end{array}$ & $\begin{array}{l}/ \mathrm{J} / \\
/ \mathrm{gaj} /\end{array}$ & 'seven' \\
\hline $\begin{array}{l}*_{\text {ttz }} \\
*_{\text {kittza(?) }}\end{array}$ & $\begin{array}{l}<\mathrm{s}> \\
<\text { quis(iquí) }>\end{array}$ & $\begin{array}{l}\text { /s/ } \\
\text { /gis/ }\end{array}$ & $\begin{array}{l}/ \mathrm{t} \mathrm{f} / \\
/ \mathrm{Jit} f /\end{array}$ & 'hair' \\
\hline $\begin{array}{l}* \text { tz } \\
*\left(\mathrm{k}^{\mathrm{w}} \mathrm{e}-\right) \text { tzina? }\end{array}$ & $\begin{array}{l}<11> \\
<1 \text { liní }>\end{array}$ & $\begin{array}{l}|z| \\
\mid z i p /\end{array}$ & $\begin{array}{l}\text { /dz/ } \\
\text { /dzin/ }\end{array}$ & 'deer' \\
\hline $\begin{array}{l}* \text {-kk- } \\
*_{\text {yekkek }}\end{array}$ & $\begin{array}{l}<\mathrm{c}> \\
<\text { yc(anré) }>\end{array}$ & $\begin{array}{l}\text { /h/ } \\
/ \mathrm{ih} /\end{array}$ & $\begin{array}{l}/ \mathrm{k} / \\
/ \mathrm{ik} /\end{array}$ & 'head' \\
\hline $\begin{array}{l}{ }^{*} \mathrm{k} \\
{ }^{*} \mathrm{ke} \text { ?la }\end{array}$ & $\begin{array}{l}<\text { qui }> \\
<\text { quial(dó)> }\end{array}$ & $\begin{array}{l}\text { /dz/ } \\
\text { /dzal (doo)/ }\end{array}$ & 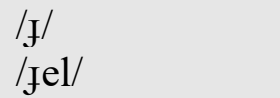 & 'lake' \\
\hline
\end{tabular}

Table 24. Selected Papabuco cognates 
Acknowledgment. I am grateful to late Thomas C. Smith Stark for sharing with me copies of the Peñafiel vocabulary from San Juan Elotepec and of his transcription of the vocabulary, and to the anonymous reviewers for their valuable comments and suggestions.

\section{References}

Alvar, Manuel. 1965-1966. Algunas cuestiones fonéticas del español hablado en Oaxaca

(México). Nueva Revista de Filología Hispánica 18.353-377.

Avelino, Heriberto. 2001. The phonetic correlates of fortis-lenis in Yalálag Zapotec consonants. University of California Los Angeles M.A. Thesis.

Belmar, Francisco. 1901. Breve noticia del idioma papabuco del pueblo de Elotepec. Oaxaca: Imprenta del Comercio.

Bright, William. 1967. Inventory of descriptive materials. In Handbook of Middle American Indians, vol. 5, Linguistics, Norman A. McQuown (ed), 9-62. Austin: University of Texas Press.

Eberhard, David M., Gary F. Simons, and Charles D. Fennig (eds.). 2019. Ethnologue: Languages of the World. 22nd ed. Dallas, Texas: SIL International. Online version: http://www.ethnologue.com.

INEGI (Instituto Nacional de Estadística y Geografía (México)). 2009. 125 años de la Dirección General de Estadística: 1882-2007. Online at https://unstats.un.org/unsd/wsd/docs/Mexico_wsd_125 anos_DGE.pdf.

Kaufman, Terrence. 2016. Proto-Sapotec(an) reconstructions. University of Pittsburgh Manuscript. Online at https://www.albany.edu/ims/pdlma/SapRec16\%20for\%20posting.pdf.

Lope Blanch, José M. 1966. Sobre el rehilamiento de 11/y en México. Anuario de Letras 6.43-60.

Mechling, William H. 1912. The Indian linguistic stocks of Oaxaca. American Anthropologist n.s. 14.643-682.

Nellis, Donald G. \& Barbara E. Hollenbach. 1980. Fortis versus lenis in Cajonos Zapotec phonology. International Journal of American Linguistics 46.92-105.

Operstein, Natalie. 2002. First-person plural and the aspect morphology of Zapotec. In Jeanie Castillo (ed), Proceedings from the Fifth Workshop on American Indigenous Languages, April 26-28, 2002, 53-64. Santa Barbara: Santa Barbara Papers in Linguistics 13.

Operstein, Natalie. 2005. Spanish loanwords and the historical phonology of Zaniza Zapotec. In Rosemary Beam de Azcona \& Mary Paster (eds), Papers from the Conference on Otomanguean and Other Oaxacan Languages, 107-116. Berkeley: Survey of California and Other Indian Languages Report 13.

Operstein, Natalie. 2012. Proto-Zapotec *tty/*ty and *ttz/*tz. International Journal of American Linguistics 78.1-40.

Operstein, Natalie. 2015a. Zaniza Zapotec. Munich: Lincom Europa.

Operstein, Natalie. 2015b. Valence-altering operations in Zaniza Zapotec. In Natalie Operstein \& Aaron Huey Sonnenschein (eds), Valence Changes in Zapotec: Synchrony, Diachrony, Typology, 175-190. Amsterdam/Philadephia: John Benjamins.

Operstein, Natalie. 2016. Phonological adaptation of Spanish loanwords in Zaniza Zapotec. International Journal of American Linguistics 82.211-238.

Operstein, Natalie. 2017a. Suppletion in Zapotec. Linguistics 55.739-782.

Operstein, Natalie. 2017b. Loanword evidence for dialect mixing in colonial American Spanish. 
In Language Contact and Change in Mesoamerica and Beyond, Karen Dakin, Claudia Parodi \& Natalie Operstein (eds), 171-186. Amsterdam/Philadelphia: John Benjamins.

Parodi, Claudia. 1995. Orígenes del español americano, vol. 1, Reconstrucción de la pronunciación. Mexico City: Universidad Nacional Autónoma de México.

Parodi, Claudia. 2017. Spanish loanwords in Amerindian languages and their implications for the reconstruction of the pronunciation of Spanish in Mesoamerica. In Language Contact and Change in Mesoamerica and Beyond, Karen Dakin, Claudia Parodi \& Natalie Operstein (eds), 155-169. Amsterdam/Philadelphia: John Benjamins.

Peñafiel, Antonio. 1880-1894. Lenguas indígenas de Oaxaca. La Sección de Antropología del Instituto de Historia de la Universidad Nacional Autónoma de México Manuscript. ${ }^{15}$

Peñafiel, Antonio. 1897. Cuestión núm. 31.-División y clasificación de las lenguas y dialectos que usaron los antiguos habitantes del actual territorio mexicano.- Su estado presente. In Congreso Internacional de Americanistas, Actas de la Undécima Reunión, México, 1895, 91-96. Mexico City: Agencia Tipográfica de F. Díaz de León.

Pickett, Velma B., María Villalobos Villalobos \& Stephen A. Marlett. 2010. Isthmus (Juchitán) Zapotec. Journal of the International Phonetic Association 40.365-372.

Rendón, Juan José. 1971. Relaciones externas del llamado idioma papabuco. Anales de Antropología 8.213-231.

Smith Stark, Thomas S. 1999. El solteco y el zapoteco occidental: un aprecio a partir de los vocabularios de Peñafiel. Paper presented at the V Congreso Nacional de Lingüística, Monterrey, Nuevo León, México.

Smith Stark, Thomas S. 2003. La ortografía del zapoteco en el Vocabvlario de fray Juan de Córdova. In Escritura zapoteca: 2500 años de historia, María de los Ángeles Romero Frizzi (ed), 173-240. Mexico City: CIESAS / Miguel Ángel Porrúa / Conaculta / INAH.

Smith Stark, Thomas C. 2007. Los préstamos entre el español y el zapoteco de San Baltasar Chichicapan. UniverSOS 4.9-39.

Speck, Charles H. 1978. The phonology of Texmelucan Zapotec verb irregularity. University of North Dakota M.A. Thesis.

Speck, Charles H. 2005a. Vocabulario zapoteco (parte zapoteco - español). Summer Institute of Linguistics Manuscript.

Speck, Charles H. 2005b. Verbos irregulares: zapoteco de San Lorenzo Texmelucan. Summer Institute of Linguistics Manuscript.

Suárez, Jorge A. 1972. La clasificación del papabuco y del solteco. Anuario de Letras 10.219232.

Uchihara, Hiroto. 2016. La pérdida de la vocal átona en zapoteco central. Paper presented at the 7th Coloquio Sobre Lenguas Otomangues y Vecinas, Oaxaca, April 2016.

\section{Appendix}

The table below presents the proposed transcription as well as a possible phonological and morphological analysis of the responses to the Peñafiel vocabulary from San Juan Elotepec. The first column shows the item's number in the Peñafiel vocabulary, the second column contains the Spanish prompt, and the third column gives the corresponding response in Elotepec; both the

\footnotetext{
15 This is the way the Peñafiel manuscript is cited in Suárez (1972: 231).
} 
prompt and the response are given in the original orthography, except for capitalization, which has been eliminated. When the Elotepec response contains an apparent typo, the hypothesized intended form follows the actual form in brackets. The fourth and fifth columns contain the proposed phonological analysis and morphological breakdown of the Elotepec response; the affixes and clitics are separated from each other and the other morphemes by dashes, and the compound constituents are separated from each other by a blank space. The animacy and nominalization markers are indicated only where practicable. The last column supplies the glosses in English; if the Elotepec response differs from the one intended by the Spanish prompt, the prompt and the response are glossed separately, with the two glosses separated by a slash.

\begin{tabular}{|c|c|c|c|c|c|}
\hline No & $\begin{array}{l}\text { SPANISH } \\
\text { PROMPT }\end{array}$ & $\begin{array}{l}\text { ELOTEPEC } \\
\text { RESPONSE }\end{array}$ & $\begin{array}{l}\text { PHONOLOGICAL } \\
\text { ANALYSIS }\end{array}$ & $\begin{array}{l}\text { MORPHOLOGICAL } \\
\text { ANALYSIS }\end{array}$ & GLOSS \\
\hline 1 & dios & chuyé & /dzuze/ & & God \\
\hline 2 & sacerdote & uxé & /uze/ & & priest \\
\hline 3 & templo & guexé & /weze/ & & church \\
\hline 4 & hombre & yquieyé & /ig'eje/ & /i-g'eje/ & $\operatorname{man}$ \\
\hline 5 & mujer & binián & /bijã/ & /bin-ã/ & $\begin{array}{l}\text { woman / my } \\
\text { wife }\end{array}$ \\
\hline 6 & muchacho & ycuené & /ik ene/ & /i-k ${ }^{\mathrm{w}} \mathrm{ene} /$ & boy \\
\hline 7 & muchacha & encuenébiniá & /enk ${ }^{\mathrm{w}}$ enebina/ & /en-k ${ }^{\mathrm{w}}$ ene bina/ & girl \\
\hline 8 & niño ó niña & $\begin{array}{l}\text { embedo ó } \\
\text { bedoré }\end{array}$ & $\begin{array}{l}\text { /enbedo/, } \\
\text { /bedore/ }\end{array}$ & $\begin{array}{l}\text { /en-bedo/, } \\
\text { /bedo-re/ }\end{array}$ & child \\
\hline 9 & $\begin{array}{l}\text { mi padre, } \\
\text { dice el hijo }\end{array}$ & usanré & /uzãre/ & /uz-ã-re/ & $\begin{array}{l}\text { my father, } \\
\text { says the son }\end{array}$ \\
\hline 10 & " " dice la hija & usanré & /uzãre/ & /uz-ã-re/ & $\begin{array}{l}\text { " " } \\
\text { says the } \\
\text { daughter }\end{array}$ \\
\hline 11 & $\begin{array}{l}\text { mi madre, } \\
\text { dice el hijo }\end{array}$ & naré & /nãre/ & /n-ã-re/ & $\begin{array}{l}\text { my mother, } \\
\text { says the son }\end{array}$ \\
\hline 12 & " " dice la hija & naré & /nãre/ & /n-ã-re/ & $\begin{array}{l}\text { " " } \\
\text { says the } \\
\text { daughter }\end{array}$ \\
\hline 13 & mi marido & niaré & /jãre/ & /n-ã-re/ & my husband \\
\hline 14 & mi esposa & biniaré & /bijãre/ & /bin-ã-re/ & my wife \\
\hline 15 & $\begin{array}{l}\text { mi hijo, dice } \\
\text { el padre }\end{array}$ & ynquillanré & /ingifãre/ & /in gif-ã-re/ & $\begin{array}{l}\text { my son, says } \\
\text { the father }\end{array}$ \\
\hline 16 & $\begin{array}{l}\text { mi hijo, dice } \\
\text { la madre }\end{array}$ & ynquillanré & /ingifãre/ & /in gif-ã-re/ & $\begin{array}{l}\text { my son, says } \\
\text { the mother }\end{array}$ \\
\hline 17 & $\begin{array}{l}\text { mi hija, dice } \\
\text { el padre }\end{array}$ & ynquillanré & /ingifãre/ & /in gif-ã-re/ & $\begin{array}{l}\text { my daughter, } \\
\text { says the father }\end{array}$ \\
\hline 18 & $\begin{array}{l}\text { mi hija, dice } \\
\text { la madre }\end{array}$ & $\begin{array}{l}\text { ynquillaré } \\
\text { (ynquillanré) }\end{array}$ & /ingifãre/ & /in gif-ã-re/ & $\begin{array}{l}\text { my daughter, } \\
\text { says the } \\
\text { mother }\end{array}$ \\
\hline 19 & $\begin{array}{l}\text { mi hermano } \\
\text { mayor }\end{array}$ & bichibalanré & /bitfibalãre/ & /bitfi bal-ã-re/ & $\begin{array}{l}\text { my elder } \\
\text { brother }\end{array}$ \\
\hline 20 & mi hermano & bichimiaré & /bitfimiãre/ & /bitfi mi-ã-re/ & my younger \\
\hline
\end{tabular}




\begin{tabular}{|c|c|c|c|c|c|}
\hline 21 & $\begin{array}{l}\text { menor } \\
\text { mi hermana } \\
\text { mayor }\end{array}$ & zan balanré & /zan balãre/ & /zan bal-ã-re/ & $\begin{array}{l}\text { brother } \\
\text { my elder } \\
\text { sister }\end{array}$ \\
\hline 22 & $\begin{array}{l}\text { mi hermana } \\
\text { menor }\end{array}$ & $\begin{array}{l}\text { zan maré } \\
\text { (zan miaré) }\end{array}$ & /zan miãre/ & /zan mi-ã-re/ & $\begin{array}{l}\text { my younger } \\
\text { sister }\end{array}$ \\
\hline 23 & indio & ynchí & /indzi/ & & Indian \\
\hline 24 & gente & beché & $/(\mathrm{m})$ bet $\int \mathrm{e} /$ & & people \\
\hline 25 & cabeza & ycanré & /ikãre/ & /ik-ã-re/ & $\begin{array}{l}\text { head / my } \\
\text { head }\end{array}$ \\
\hline 26 & pelo & quisiquí & /gisiki/ & /gis iki/ & $\begin{array}{l}\text { hair / head } \\
\text { hair }\end{array}$ \\
\hline 27 & cara & loná & /lona/ & /lo-na/ & $\begin{array}{l}\text { face / } \\
\text { our face }\end{array}$ \\
\hline 28 & frente & tegaán & /tegaã/ & /te-ga-ãa/ & $\begin{array}{l}\text { forehead / my } \\
\text { forehead }\end{array}$ \\
\hline 29 & oreja & ydagaán & /idagaã/ & /i-daga-ã/ & $\begin{array}{l}\text { ear / } \\
\text { my ear }\end{array}$ \\
\hline 30 & ojo & urloná & /urlona/ & /ur lo-na/ & $\begin{array}{l}\text { eye / } \\
\text { our eye }\end{array}$ \\
\hline 31 & nariz & tiñia & /tija/ & & nose \\
\hline 32 & boca & runá & /runa/ & /ru-na/ & $\begin{array}{l}\text { mouth / our } \\
\text { mouth }\end{array}$ \\
\hline 33 & lengua & luxná & /luzna/ & /luz-na/ & $\begin{array}{l}\text { tongue / our } \\
\text { tongue }\end{array}$ \\
\hline 34 & dientes & leyná & /lejna/ & /lej-na/ & $\begin{array}{l}\text { teeth / our } \\
\text { teeth }\end{array}$ \\
\hline 35 & barba & quisiruná & /gisiruna/ & /gisi ru-na/ & $\begin{array}{l}\text { beard / our } \\
\text { beard }\end{array}$ \\
\hline 36 & cuello & nierrieñá & /nerjena/ & /ner jeja/ & neck \\
\hline 37 & brazo & hianá & /jana/ & /ja-na/ & $\begin{array}{l}\text { arm / } \\
\text { our arm }\end{array}$ \\
\hline 38 & mano & hianá & /jana/ & /ja-na/ & $\begin{array}{l}\text { hand / our } \\
\text { hand }\end{array}$ \\
\hline 39 & dedos & bizná & /(m)bizna/ & /(m)biz-na/ & $\begin{array}{l}\text { fingers / our } \\
\text { fingers }\end{array}$ \\
\hline 40 & dedo pulgar & bisilná & /(m)bizilna/ & /(m)biz il-na/ & $\begin{array}{l}\text { thumb / our } \\
\text { thumb }\end{array}$ \\
\hline 41 & uñas & choquianá & /tfogjana/ & /t $\int$ og ja-na/ & $\begin{array}{l}\text { nails / our } \\
\text { nails }\end{array}$ \\
\hline 42 & cuerpo & betbalná & /betbalna/ & /bet bal-na/ & $\begin{array}{l}\text { body / our } \\
\text { body }\end{array}$ \\
\hline 43 & pecho & lerán & /lerã/ & /ler-ãa/ & $\begin{array}{l}\text { breast / my } \\
\text { breast }\end{array}$ \\
\hline 44 & barriga & ticiudán & /(?)ã/ & $/(?)-\tilde{a} /$ & $\begin{array}{l}\text { belly / my } \\
\text { belly }\end{array}$ \\
\hline 45 & pechos de & lecbinián & /le(g')binã/ & /le(g') bin-ã/ & woman's \\
\hline
\end{tabular}


mujer

breasts / my

46 pierna

cuirán

$/ \mathrm{k}^{\mathrm{w}} \mathrm{i}$ ã $/$

$/ \mathrm{k}^{\mathrm{w}} \mathrm{i}-\tilde{\mathrm{a}} /$

wife's breasts

\section{7}

7 pié

quianá

/g'ana/

/g'a-na/

/(m)bizg'ãre/

/(m)biz g'-ã-re/

/riti/

49 hueso

riti

50 corazon

lerná

/lerna/

/ler-na/

51 sangre

reñié

/rene/

52 pueblo, villa, tiguyé

aldea

(tigueyé),

/tigeze/,

/bili/, villi, renyé

/rene/

53 jefe

jefeson

/hefesõ/ (?)

(?)

ygqui, eryú

ymigaré

/imigare/

yagilo

yuhú

/jagilo/

/ju'/

/ju'duzãwagize/

yuhu

dusanguaquiyé

rubá

/ruba/

serupinieyé

/zerupijedze/

60 caldera

$$
\text { serupinieyé }
$$$$
\text { /zerupijnedze/ }
$$

$\begin{array}{ll}61 & \text { arco } \\ 62 & \text { flecha } \\ 63 & \text { hacha } \\ 64 & \text { cuchillo } \\ 65 & \text { canoa } \\ 66 & \text { guarache ó } \\ & \text { zapato } \\ 67 & \text { pipa }\end{array}$

xilquité

$/ \int i 1 k^{\mathrm{w}}$ ite/

fleche essón

/fletfesõ/ (?)

quibiagá

/gibjaga/

quis quibé

/gis gibe/

canoré

/kanore/

quitlabá,

labiquidé

/gidlaba/,

/labigide/

niersobruyá /

barril ó

cachimba

/nierzobruja/

/ il k $\mathrm{k}^{\mathrm{w} i t e /}$

/flet fe-sõ/ (?)

/hefe-sõ/

(?)

/imiga-re/

/jag ilo/

leg /

my leg

foot /

our feet

toes /

my toes

bone

heart / our

heart

blood

town, village,

hamlet

boss

warrior

friend

cradle

house

/ju' du-zãwa (?) thatch hut

gize/

/ru ba/

tomb

/ze rupi nedze/

cauldron /

where clothes

are washed

bow / rainbow

/gib jaga/

arrow

/gis gibe/

axe

knife

/kano-re/

trough

/gid laba/,

/labi gide/

sandal or shoe

/ni er-zob ru-j/

pipe / what he

puts in his

mouth or

what is in his

mouth

$\begin{array}{lll}68 & \text { tabaco } & \text { tabaueré } \\ 69 & \text { cielo } & \text { baré } \\ 70 & \text { sol } & \text { doré } \\ 71 & \text { luna } & \text { beyé } \\ 72 & \text { estrella } & \text { cuiilré } \\ 73 & \text { dia } & \text { lliná }\end{array}$

/tabawere/
/bare/
/dore/
/beje/
/gwiilre/
/zína/

/tabawe-re/

/ba-re/

tobacco

sky

/do-re/

sun

moon

$/ g^{\mathrm{w}} \mathrm{i}$ il-re/

star /

big star

day /

/zi na/

this day 


\begin{tabular}{|c|c|c|c|c|c|}
\hline 74 & noche & ralná & /rálna/ & /ral na/ & $\begin{array}{l}\text { night / this } \\
\text { night }\end{array}$ \\
\hline 75 & mañana & hersilná & /ersilna/ & /er-sil-na/ & $\begin{array}{l}\text { morning / we } \\
\text { eat breakfast }\end{array}$ \\
\hline 76 & tarde & huillé & /wize/ & & afternoon \\
\hline 77 & primavera & tiomgieyé & /tjomg'eje/ & /tjom g'eje/ & $\begin{array}{l}\text { spring / rainy } \\
\text { season }\end{array}$ \\
\hline 78 & verano & tieomerrubiy & /tjomerubi/ & /tjom erubi/ (?) & $\begin{array}{l}\text { summer / (?) } \\
\text { season }\end{array}$ \\
\hline 79 & otoño & tieonquasá & /tjomwasa/ & /tjom wasa/ & $\begin{array}{l}\text { fall / dry } \\
\text { season }\end{array}$ \\
\hline 80 & invierno & vizgraená & $(?)$ & $(?)$ & winter \\
\hline 81 & viento & viy & /bi/ & & wind \\
\hline 82 & trueno & herniquiuxi & /ernigiuzi/ & /er-ni gi uzi/ & thunder \\
\hline 83 & relámpago & $\begin{array}{l}\text { heryiloquixi } \\
\text { (heryiloquiuxi) }\end{array}$ & /erfilogiuzi/ & /er-Ji lo gi uzi/ & lightning \\
\hline 84 & lluvia & quieiyé & /g'eje/ & & rain \\
\hline 85 & nieve & yta quieyé & /ita g'eje/ & /i-ta g'eje/ & snow \\
\hline 86 & fuego & guiyé & /gije/ & & fire \\
\hline 87 & agua & nisi & /nisi/ & & water \\
\hline 88 & hielo & quiegué & /g'ege/ & & ice \\
\hline 89 & tierra & yú & /ju/ & & earth \\
\hline 90 & mar & dó & $/ \mathrm{do} /$ & & sea \\
\hline 91 & rio & guiagua & /g'awa/ & & river \\
\hline 92 & lago & quialdó & /g'aldo/ & /g'al do/ & lake \\
\hline 93 & valle & $\begin{array}{l}\text { lechilgré } \\
\text { (lechilré) }\end{array}$ & /letfilre/ & /let il-re/ & $\begin{array}{l}\text { valley / big } \\
\text { valley }\end{array}$ \\
\hline 94 & llano & lechimiré & /letfimire/ & /letfi mi-re/ & $\begin{array}{l}\text { plain / small } \\
\text { valley }\end{array}$ \\
\hline 95 & $\begin{array}{l}\text { cerro, } \\
\text { montaña }\end{array}$ & $\begin{array}{l}\text { las ibré } \\
\text { (las ilré) }\end{array}$ & /las ilre/ & /las il-re/ & $\begin{array}{l}\text { hill, mountain } \\
\text { / large hill }\end{array}$ \\
\hline 96 & isla & layú ullré & /laju uzre/ (?) & /laju uz-re/ & $\begin{array}{l}\text { island / small } \\
\text { (?) }\end{array}$ \\
\hline 97 & piedra, roca & heita illi & /ita ili/ & /i-ta ili/ & $\begin{array}{l}\text { stone, rock / } \\
\text { large stone }\end{array}$ \\
\hline 98 & sal & zedé & /zede/ & & salt \\
\hline 99 & cobre & guibequesé & /gíbekese/ & /gibe kese/ & copper \\
\hline 100 & plata & guibitimienñá & /gibitimina/ & /gibi timina/ & silver \\
\hline 101 & oro & heitaquibiora & /itagibiora/ & /i-ta gibi ora/ & gold \\
\hline 102 & $\begin{array}{l}\text { bosque, } \\
\text { selva }\end{array}$ & laquí ilí & /lagi ili/ & /lagi ili/ & $\begin{array}{l}\text { woods, forest } \\
\text { / large (?) }\end{array}$ \\
\hline 103 & arbol & 1laegrellé & /jagre(?)e/ & /jag re(?)e/ & tree / (?) tree \\
\hline 104 & madera & lliagá & /jaga/ & & wood \\
\hline 105 & hoja & leagá & /Kaga/ & & leaf \\
\hline 106 & corteza & ledé & /lede/ & & bark \\
\hline
\end{tabular}




\begin{tabular}{|c|c|c|c|c|c|}
\hline 107 & yerba & liagré & /Kagre/ & /Kag-re/ & grass \\
\hline 108 & pino & billisí & /bizizi// & /bi-zizizi/ & $\begin{array}{l}\text { pine tree / } \\
\text { pineapple }\end{array}$ \\
\hline 109 & maíz & obá & /oba/ & & corn \\
\hline 110 & frijol & ursá & /urza/ & /ur za/ & beans \\
\hline 111 & calabaza & guieté & /g'ete/ & & squash \\
\hline 112 & $\begin{array}{l}\text { chile, } \\
\text { pimiento }\end{array}$ & guiñí & /gini// & & chili, pepper \\
\hline 113 & carne & balá & /bala/ & & meat \\
\hline 114 & murciélago & beigidebesinnís & /begidebezinis/ & /be-gide be-zini-s/ & bat \\
\hline 115 & perro & beco & /beko/ & & $\operatorname{dog}$ \\
\hline 116 & coyote & yieñé & /jene/ (?) & & coyote \\
\hline 117 & tigre & tigreson & /tigresõ/ (?) & /tigre-sõ/ & tiger \\
\hline 118 & oso & banasé & /banaze/ (?) & & bear \\
\hline 119 & leon, puma & bizquixé & /bizgife/ & /biz_gife/ & lion, puma \\
\hline 120 & lobo & bizquiasá & /bizg'aza/ (?) & /biz g'aza/ & wolf \\
\hline 121 & zorra & bití & /biti/ & & fox / skunk \\
\hline 122 & tejon & chixhé & /zize/ & & coati \\
\hline 123 & ciervo & lliní & /zini/ & & deer \\
\hline 124 & jabalí & cusquillé & /kusgife/ & /kus gife/ & wild boar \\
\hline 125 & armadillo & bixi & /bizi/ & & armadillo \\
\hline 126 & raton & bixinñí & /bizini/ & /bi-zini/ & mouse \\
\hline 127 & conejo & biltí (billí) & /bisi/ & & rabbit \\
\hline 128 & ardilla & brisi & /brizi/ & /b-rizi/ & squirrel \\
\hline 129 & tortuga & tortuga & /tortuga/ & & turtle \\
\hline 130 & lagartija & bizquidí & /bizgidi/ & /biz̨gidi/ & lizard \\
\hline 131 & caballo & baña & /bana/ & & horse \\
\hline 132 & mosca & ezquiegué & /esg'ege/ & /es-g'ege/ & fly \\
\hline 133 & mosquito & esquienú & /esg'enu/ & /es-g'enu/ & mosquito \\
\hline 134 & sapo & berlabá & /berlaba/ & /ber laba/ & toad \\
\hline 135 & $\begin{array}{l}\text { culebra, } \\
\text { serpiente }\end{array}$ & $\begin{array}{l}\text { biti quillé } \\
\text { (bili quillé) }\end{array}$ & /bili gife/ & /bili gife/ & snake \\
\hline 136 & $\begin{array}{l}\text { culebra de } \\
\text { cascabel }\end{array}$ & billesié & /billeze/ (?) & /bil leze/ (?) & rattlesnake \\
\hline 137 & alacran & guinec & /winek/ or /wine?/ & /wine-k/ (?) & scorpion \\
\hline 138 & ave & esquinloyec & $\begin{array}{l}\text { /esginlojek/or } \\
\text { /esginloje?/ }\end{array}$ & $\begin{array}{l}\text { /es-gin lojek/ or } \\
\text { /es-gin loje?/ (?) }\end{array}$ & bird \\
\hline 139 & huevo & go & $/(\mathrm{y}) \mathrm{go} /$ & & egg \\
\hline 140 & plumas & debé & /debe/ & & feather \\
\hline 141 & alas & loxilná & /lofilna/ & /lo Jil-na/ & wings $^{19}$ \\
\hline 142 & ganso & gansex & /gansef/ (?) & /ganse-f/ (?) & goose \\
\hline 143 & pato & badá & /bada/ & & duck \\
\hline 144 & zopilote & lieyé & / $\mathrm{Ke} \int \mathrm{e} /$ & & buzzard $^{16}$ \\
\hline
\end{tabular}

\footnotetext{
${ }^{16}$ The initial letter of Nos. 141 and 144 appears to be the same. It is assumed to be $<1>$ based on comparison with
} the likely cognates of these words: No. 141 <loxilná> 'wings' is assumed to be related to /lowe'/ 'wing' in 


\begin{tabular}{|c|c|c|c|c|c|}
\hline 145 & cuervo & ezquincazá & /esginkasa/ & /es-gin kasa/ & crow \\
\hline 146 & guajolote & cola & /kola/ & & turkey \\
\hline 147 & paloma & uraga & /uraga/ & & dove \\
\hline 148 & pez & balsedé & /balzede/ & /bal zede/ & $\begin{array}{l}\text { fish / salted } \\
\text { fish (?) }\end{array}$ \\
\hline 149 & $\begin{array}{l}\text { bobo, } \\
\text { pescado }\end{array}$ & balá & /bala/ & & fish sp. \\
\hline 150 & bagre & bal nullelmá & /bal nuJelma/ (?) & bal nuJelma (?) & catfish \\
\hline 151 & anguila & bili nullelmá & /bili nufelma/ (?) & bili nufelma (?) & eel \\
\hline 152 & nombre & bilñici & /bilñisi/ & /bil nisi/ & $\begin{array}{l}\text { name / water } \\
\text { snake }^{17}\end{array}$ \\
\hline 153 & blanco & quicheguesé & /kitfekese/ & /kitfe kese/ & white \\
\hline 154 & negro & encasá & /enkasa/ & /en-kasa/ & black \\
\hline 155 & colorado & eññan & /enna/ & /en-na/ & red \\
\hline 156 & azul celeste & encaá & /enka'/ & /en-ka'/ & sky-blue \\
\hline 157 & amarillo & enquesé & /enkese/ & /en-kese/ & yellow \\
\hline 158 & verde & enquiné & /enkine/ & /en-kine/ & green \\
\hline 159 & grande & enhili & /enili/ & /en-ili/ & big \\
\hline 160 & pequeño & enmihi & /enmi'/ & /en-mi'/ & small \\
\hline 161 & fuerte & robrú & /robru/ & /rob-ru/ & $\begin{array}{l}\text { strong / you } \\
\text { are strong }\end{array}$ \\
\hline 162 & viejo & ygalá & /igala/ & /i-gala/ & old (man) \\
\hline 163 & jóven & solteré & /soltere/ & & young (man) \\
\hline 164 & bueno & napia & /napja/ & /nap-ja/ & $\begin{array}{l}\text { good / he is } \\
\text { good }\end{array}$ \\
\hline 165 & malo & tenyia & /tenja/ & /tej-ja/ & $\mathrm{bad} / \mathrm{he}$ is bad \\
\hline 166 & muerto & ytó & /ito/ & /i-to/ & dead (person) \\
\hline 167 & vivo & zanayaá & /zanaja/ (?) & /zana-ja/ (?) & $\begin{array}{l}\text { alive / he is } \\
\text { alive (?) }\end{array}$ \\
\hline 168 & frio & rayá & /raja/ & & cold \\
\hline 169 & caliente & bexiguí & /bezigi/ & /be-zigi/ & hot \\
\hline 170 & yo & aan & $/ \tilde{\mathrm{a}} /$ & & I \\
\hline 171 & tú & ruú & $/ \mathrm{ru} /$ & & you (sg.) \\
\hline 172 & él & yrsé & /irze/ & /i-^-ze/ & he \\
\hline 173 & nosotros & biegniá & (?) & bieg-nia (?) & we \\
\hline 174 & vosotros & bigaaná & (?) & big-aana (?) & you (pl.) \\
\hline 175 & ellos & bicailié & (?) & bic-ailie (?) & they \\
\hline 176 & este & yiesán & /jezã/ (?) & & this \\
\hline 177 & aquel & yrecáá & /ireka/ & /i-re-ka/ (?) & that \\
\hline 178 & todo, todos & ydelní & /idelni/ & /i-del-ni/ & all \\
\hline 179 & $\begin{array}{l}\text { mucho, } \\
\text { muchos }\end{array}$ & bierobbigía & /birobigia/ (?) & /bi-rob igia/ & much, many ${ }^{18}$ \\
\hline
\end{tabular}

Texmelucan Zapotec and / $\mathrm{fiK} /$ 'wing' in Zaniza Zapotec, and No. $144<$ lieyé $>$ 'buzzard' is assumed to be cognate with the word for 'buzzard' in Texmelucan Zapotec $(/ \kappa \mathrm{a} / /)$ and Zaniza Zapotec $(/ \mathrm{Ke} / /)$.

${ }^{17}$ See Table 23 above and the accompanying discussion.

${ }^{18} \mathrm{Cf}$. < bi-goroba> 'many' in Rendón (1971: 223). 


\begin{tabular}{|c|c|c|c|c|c|}
\hline 180 & quien & chumdec & $\begin{array}{l}\text { /t } \text { fumdek/ or } \\
\text { /t } \text { fumde?/ }\end{array}$ & $\begin{array}{l}\text { /tfum-dek/ or } \\
\text { /tfum-de?/ }\end{array}$ & who \\
\hline 181 & léjos & zecto & /zePto/ (?) & & far \\
\hline 182 & cerca de & gabá & /gaba/ & & near \\
\hline 183 & aquí & ylá & /ila/ & & here \\
\hline 184 & allá & yuní & /juni/ & & there \\
\hline 185 & hoy & naá & /na/ & & today \\
\hline 186 & ayer & nagée & /nage/ & & yesterday \\
\hline 187 & $\begin{array}{l}\text { mañana (el } \\
\text { dia de) }\end{array}$ & galibé & /galibe/ & & tomorrow \\
\hline 188 & sí & han & ã (?) & & yes \\
\hline 189 & no & haan & $\tilde{a}^{\prime}(?)$ & & no \\
\hline 190 & uno & tibi & /tibi/ & & one \\
\hline 191 & dos & chabá & $/ \mathrm{t} \int \mathrm{aba} /$ & & two \\
\hline 192 & tres & zosná (zoná) & /sona/ & & three \\
\hline 193 & cuatro & tapa & /tapa/ & & four \\
\hline 194 & cinco & guiyé & /gije/ & & five \\
\hline 195 & seis & llopa & / Jopa/ & & $\operatorname{six}$ \\
\hline 196 & siete & gueché & /gedze/ & & seven \\
\hline 197 & ocho & lumní (llunní) & / Juni/ & & eight \\
\hline 198 & nueve & gá & /ga/ & & nine \\
\hline 199 & diez & chís & $/ \mathrm{t} \int \mathrm{is} /$ & $/ \mathrm{t} \int \mathrm{i}-\mathrm{s} /(?)$ & ten \\
\hline 200 & once & chibitubi & /t $\int i b i t u b i /$ & /t fi-bi-tubi/ & eleven \\
\hline 201 & doce & chibechopa & /tfibitfopa/ & $/ \mathrm{t} \int \mathrm{i}-\mathrm{bi}-\mathrm{t} \int \mathrm{pop} /$ & twelve \\
\hline 202 & veinte & galá & /gala/ & & twenty \\
\hline 203 & treinta & galrebechí & /galrebitfi/ & /gal-rebi-t $\int \mathrm{i} /$ & thirty \\
\hline 204 & cuarenta & chó & $/ \mathrm{t} \int \mathrm{o} /$ & & forty \\
\hline 205 & cincuenta & chalnalá & /tfalnala/ & /t fal nala/ & fifty \\
\hline 206 & sesenta & quioná & /gijona/ & /gi-jona/ & sixty \\
\hline 207 & setenta & quionrebichí & /gijonrebitsi/ & /gi-jon-rebi-t $\int \mathrm{i} /$ & seventy \\
\hline 208 & ochenta & taa & $/ \mathrm{ta}^{\prime} /$ & & eighty \\
\hline 209 & noventa & taabichí & /ta'bit $\int 1 /$ & $/$ ta'-bi-t $\int \mathrm{i} /$ & ninety \\
\hline 210 & ciento & taabinala & /ta'binala/ & /ta'-bi-nala/ & hundred \\
\hline 211 & mil & mil & $/ \mathrm{mil} /$ & & thousand \\
\hline 212 & comer & dauna & /dawna/ & /d-aw-na/ & $\begin{array}{l}\text { to eat / } \\
\text { we eat }\end{array}$ \\
\hline 213 & beber & diena & /diena/ & /d-ie-na/ & $\begin{array}{l}\text { to drink / we } \\
\text { drink }\end{array}$ \\
\hline 214 & correr & raurú & /rawru/ & / $\mathrm{s}-\mathrm{aw}-\mathrm{ru} /$ & $\begin{array}{l}\text { to run / you } \\
\text { eat }\end{array}$ \\
\hline 215 & bailar & dalná & /dalna/ & /d-al-na/ & $\begin{array}{l}\text { to dance / we } \\
\text { dance }\end{array}$ \\
\hline 216 & cantar & dalruná & /dalruna/ & /d-al ru-na/ & $\begin{array}{l}\text { to sing / we } \\
\text { sing }\end{array}$ \\
\hline 217 & dormir & dezná & /desna/ & /d-es-na/ & $\begin{array}{l}\text { to sleep / we } \\
\text { sleep }\end{array}$ \\
\hline
\end{tabular}




\begin{tabular}{|c|c|c|c|c|c|}
\hline 218 & hablar & hiñina & /inina/ & /i-ni-na/ & $\begin{array}{l}\text { to speak / we } \\
\text { speak }\end{array}$ \\
\hline 219 & ver & higuiná & /igwina/ & /i-gwi-na/ & $\begin{array}{l}\text { to see / } \\
\text { we see }\end{array}$ \\
\hline 220 & amar & $\begin{array}{l}\text { guitiragueleranl } \\
\text { oru }\end{array}$ & /kitirakelerãloru/ & $\begin{array}{l}\text { /kiti rake ler-ã lo- } \\
\text { ru/ }\end{array}$ & $\begin{array}{l}\text { to love / I love } \\
\text { you }\end{array}$ \\
\hline 221 & matar & dutaní & /dutãni/ & /d-ut-ã(n)-i/ (?) & $\begin{array}{l}\text { to kill / I kill } \\
\text { him }\end{array}$ \\
\hline 222 & sentarse & ysoban & /izobã/ & /i-zob-ã/ & $\begin{array}{l}\text { to sit down / I } \\
\text { sit down }\end{array}$ \\
\hline 223 & $\begin{array}{l}\text { estar en pié, } \\
\text { pararse }\end{array}$ & guasonón & /wasõ/ (?) & /was-õ/ (?) & $\begin{array}{l}\text { to stand (up) / } \\
\text { I stand (up) }\end{array}$ \\
\hline 224 & ir & zabanán & /zabã/ (?) & /zab-ã/ (?) & to go / I go \\
\hline 225 & venir & yapaán & /japã/ & /jap-ã/ & $\begin{array}{l}\text { to come / I } \\
\text { come }\end{array}$ \\
\hline 226 & andar & zanán & /zaã/ & /za-ã/ & $\begin{array}{l}\text { to walk / I } \\
\text { walk }\end{array}$ \\
\hline 227 & trabajar & riniricháán & / rinicitfãa/ & /rini ritf-ã/ & $\begin{array}{l}\text { to work / I } \\
\text { work }\end{array}$ \\
\hline 228 & robar & ybana & /ibana/ & /i-bana/ & to rob / thief \\
\hline 229 & mentir & liemé & /Keme/ (?) & & to lie \\
\hline 230 & dar & risarú & /rizaru/ & /ri-za-ru/ (?) & $\begin{array}{l}\text { to give / you } \\
\text { give (?) }\end{array}$ \\
\hline 231 & reir & riená & /riena/ & /r-ie-na/ & $\begin{array}{l}\text { to laugh / we } \\
\text { laugh }\end{array}$ \\
\hline 232 & gritar & rezná & /rezna/ & /s-ez-na/ & $\begin{array}{l}\text { to shout / we } \\
\text { shout }\end{array}$ \\
\hline 233 & bramar & ruconá & /rukona/ & /ruko-na/ (?) & $\begin{array}{l}\text { to bellow / we } \\
\text { bellow (?) }\end{array}$ \\
\hline 234 & ladrar & heryímmá & /erfinma/ & /er-fin-ma/ & $\begin{array}{l}\text { to bark / it } \\
\text { barks }\end{array}$ \\
\hline 235 & cacarear & yzervezrrucaom & $\begin{array}{l}\text { /izerbezrukoma/ } \\
\text { (?) }\end{array}$ & $\begin{array}{l}\text { /iz er-bez ruko- } \\
\text { ma/ (?) }\end{array}$ & $\begin{array}{l}\text { to crow / it } \\
\text { crows (?) }\end{array}$ \\
\hline 236 & tronar & herzechí & /erzedzi/ & /er-zedzi/ & to thunder \\
\hline 237 & gótear & rabá & /raba/ & & to drip \\
\hline 238 & charlar & huniyá & /unija/ & /u-ni-ja/ & $\begin{array}{l}\text { to chat / he } \\
\text { chatted }\end{array}$ \\
\hline 239 & lloviznar & yatiguieyé & /jatig'eje/ & /jati g'eje/ & $\begin{array}{l}\text { to drizzle / it } \\
\text { rains }\end{array}$ \\
\hline 240 & gorjear & hervezná & /erbezna/ & /er-bez-na/ & $\begin{array}{l}\text { to chirp / we } \\
\text { chirp }\end{array}$ \\
\hline 241 & voluntad & hurulerán (?) & /urulerã/ & /u-ru ler-ã/ (?) & $\begin{array}{l}\text { will / my } \\
\text { heart came } \\
\text { out }(?)\end{array}$ \\
\hline
\end{tabular}

\footnotetext{
${ }^{19}$ In several of the responses, it is unclear whether the intended sequence is $<$ ler $>$ or $<$ br $>$. No. 241 is one of them, and the provisional analysis in the table depends on the assumption that it contains the sequence $<$ ler $>$.
} 


\begin{tabular}{|c|c|c|c|c|c|}
\hline 242 & memoria & zinyguá & (?) & $(?)$ & memory \\
\hline 243 & pensamiento & herhabruá & (?) & (?) & thought \\
\hline 244 & bondad & hudimbraán & (?) & $(?)$ & kindness \\
\hline 245 & amor & engueganré & /engegãre/ (?) & /en-geg-ã-re/ (?) & love \\
\hline 246 & olvido & bietíbrandí & $(?)$ & $(?)$ & oblivion \\
\hline 247 & verdad & solsí & (?) & (?) & truth \\
\hline 248 & tiempo & tiemné & /tjemne/ & /tjem-ne/ (?) & time \\
\hline 249 & razon & loliy & /loli/ & /lo li/ & reason \\
\hline 250 & pereza & becuexedé & /bek ${ }^{\mathrm{w}}$ ezede/ & /bek ${ }^{\mathrm{w}}$ e zede/ (?) & laziness \\
\hline
\end{tabular}

